Golden Gate University School of Law GGU Law Digital Commons

2019

\title{
Pulling Back the Curtain: Implicit Bias in the Law School Dean Search Process
}

Michele Benedetto Neitz

Golden Gate University School of Law, mneitz@ggu.edu

Follow this and additional works at: https://digitalcommons.law.ggu.edu/pubs

Part of the Legal Education Commons, and the Legal Profession Commons

\section{Recommended Citation}

49 Seton Hall L. Rev. 629 (2019).

This Article is brought to you for free and open access by the Faculty Scholarship at GGU Law Digital Commons. It has been accepted for inclusion in Publications by an authorized administrator of GGU Law Digital Commons. For more information, please contact jischer@ggu.edu. 


\title{
Pulling Back the Curtain: Implicit Bias in the Law School Dean Search Process
}

\author{
Michele Benedetto Neitz ${ }^{*}$
}

I.INTRODUCTION 630

II.THE UNIQUe AND ChALlenging ROLE OF A LAW SCHOOL DEAN 632

A. The Traditional Role of a Dean .....................................632

B. The Role of a Dean After the Great Recession............... 633

1. Law Deans as "Innovators" .....................................634 634

2. Law Deans as Job Placement Experts........................635

C. The Dean as a "Juggler" of Various Constituencies.......636

III.THE TyPICAL DEAN SEARCH PROCESS AND DIVERSITY OF

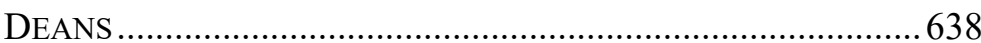

A. ABA Requirements .....................................................639

B. The Typical Dean Search Process ...................................640

1. The Players: Creating a Dean Search Committee..... 640

2. The Process: One Step at a Time ..............................642

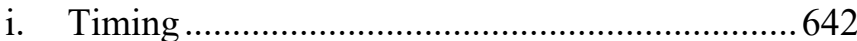

ii. Crafting the Job Description: the "Listening

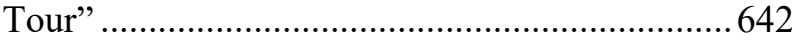

iii. Advertising the Dean Position............................644

iv. Review of Applications .......................................644

v. Screening Interviews ..........................................645

vi. Selecting Finalists, Reference Checks, and the OnCampus Visit ....................................................647 647

vii. Extending an Offer .............................................648

3. Search firms ...............................................................649

\footnotetext{
* Professor of Law, Golden Gate University School of Law. J.D., 2001, New York University School of Law; B.A., 1997, Santa Clara University. I am indebted to the many deans and former deans who agreed to speak with me both on and off the record. Special thanks to Deans Anthony Niedwiecki, Rachel Van Cleave, Dru Ramey, and Colin Crawford for their candor. I am grateful to Judge Mark W. Bennett, Professor Deborah Rhode, Professor Eric Christiansen, and Dean Rachel Van Cleave for their editing suggestions, and to Cece Fernandez for her outstanding research assistance. This Article is dedicated to Maryellen Benedetto.
} 
C. Who Becomes a Dean in American Law Schools? Decanal

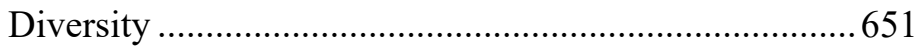

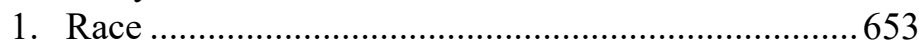

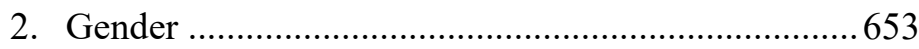

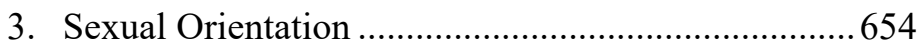

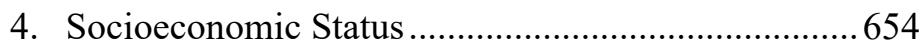

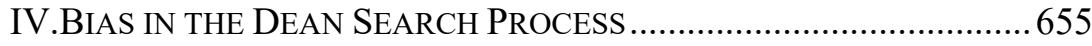

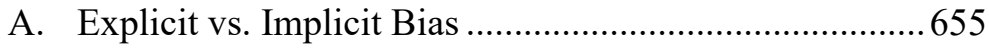

B. How Do We Know Implicit Bias Exists? .......................657

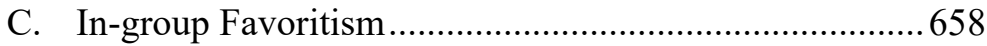

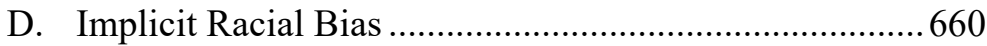

E. Implicit Gender Bias........................................................662

F. Implicit Sexual Orientation Bias .....................................664

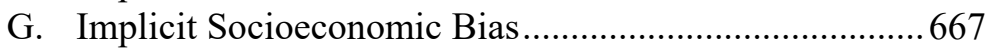

V.ReCOMmENDATIONS: How to REMEDY BIAS IN THE DEAN SEARCH

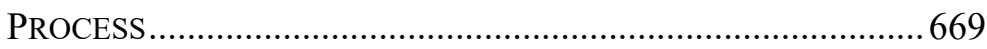

A. De-biasing Techniques for Individuals..........................669

B. De-biasing Techniques for Institutions..........................671

C. Change the Dean Search Process......................................674

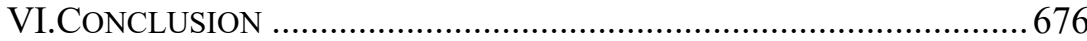

\section{INTRODUCTION}

Like judges, law school deans exercise an extraordinary amount of discretion and power. Deans, however, are more buffeted by the winds of the legal marketplace and the constantly shifting power dynamics of law schools and universities. Law school deans must serve as the public face of a law school for fundraising and marketing purposes, while simultaneously "managing up" with presidents and provosts and "managing down" to meet the needs of faculty, staff, and students.

Consequently, law schools generally search for a dean who will have the ability to serve multiple, and sometimes competing, constituencies within the law school while effectively managing the outside challenges that face their own institution and the legal education as a whole. This tall order is usually governed by a "dean search process."

The dean search process can be viewed as a bellwether for the health of a law school. Within the microcosm of a civilized "dean search committee"

1 "The 'dean search process' typically refers to the process by which a law school or university committee searches for a dean." R. Lawrence Dessem, Knowing Which Deanship Is the Right One, 31 SeAtTle U. L. REV. 783, 784 (2008). 
can lie the tensions of rival factions, attempting to impose their respective visions for the next chapter of the law school enterprise. If law school revenue is down, the factions may be fighting for their own survival.

Not surprisingly, then, the dean search process becomes a lightning rod for the stresses facing law school faculty, staff, and university administrators. As a result, the implicit biases of individuals and institutions can play a major (and often obscured) role in the selection of a dean. Although the concept of implicit bias has been extensively studied in the context of judges, ${ }^{2}$ the criminal justice system, ${ }^{3}$ and other areas, no one to date has looked at the effects of implicit bias on law dean search processes.

This Article stems from the author's experience chairing multiple dean searches and research interest in the existence, genesis, and effects of implicit bias. Part II of this Article will review the role of a law school dean, with special consideration of the ways the Great Recession and its outcomes transformed the role of the dean. Part III will describe the typical dean search process and evaluate decanal diversity statistics to determine which candidates are selected for these powerful roles in today's law schools. Part IV will introduce the concept of implicit bias, specifically focusing on ingroup favoritism. This part will also analyze the ways implicit bias can manifest itself in the dean search process, focusing on racial, gender, socioeconomic, and sexual orientation biases. ${ }^{4}$ Finally, Part V will suggest recommendations to minimize the operation and impact of implicit bias on the part of dean search committees, and will offer creative ways to improve the traditional dean search process.

2 There are two empirical studies in legal academic literature examining implicit bias in judges. Both studies found that judges manifest strong implicit biases. See Justin D. Levinson et al., Judging Implicit Bias: A National Empirical Study of Judicial Stereotypes, 69 FlA. L. REV. 63, 81 (2017) [hereinafter Levinson et al., Judging Implicit Bias] (concluding that judges hold implicit negative biases against Asian-Americans and Jews); see also Jeffrey J. Rachlinski et al., Does Unconscious Racial Bias Affect Trial Judges?, 84 Notre Dame L. REV. 1195, 1197 (2009) (concluding that state court judges harbor implicit racial biases that can affect their judgment).

3 See, e.g., Mark W. Bennett \& Victoria C. Plaut, Looking Criminal and the Presumption of Dangerousness: Afrocentric Facial Features, Skin Tone, and Criminal Justice, 51 U. C. DAVIS L. REV. 745 (2018).

4 These four types of bias are most likely to manifest in dean searches, but there are other types of potential bias, including age, disability, and religious bias. A full examination of all types of implicit bias is beyond the scope of this Article. 


\section{The UniQue AND Challenging Role of A LAW SCHOOl DEAN}

\section{A. The Traditional Role of a Dean}

The dean plays numerous roles in a law school. ${ }^{5}$ Like a college president, a dean "immediately assumes a prestigious public position in his or her community, and perhaps a state or national forum." In addition to maintaining a public profile, deans are responsible for managing the internal affairs of a law school while bearing "the awesome responsibility of educating the nation's lawyers and judges."7

The job of a law school dean has been variously described in legal academic literature as an "enviable job," a "privilege," a "challenge of unique proportions," 10 and a position offering "no satisfaction" that would only be sought by "someone who is certifiably psychotic, or at [a] minimum, seriously character-disordered." 11 Few jobs in the law are described in such conflicting ways, but these disparate views of the law school dean position may result from the fact that the job itself has always been a powerful, but difficult, one.

A seminal 1980 article explained the five roles of a law school dean as "leader, manager, energizer, envoy, [and] intellectual."12 Balancing these complicated roles is no small task, especially since they often contradict. ${ }^{13}$ For example, although deans are able to enjoy the spotlight during high profile events, the day-to-day tasks of a law dean are much more mundane. Deans must "spend a great deal of [their] time on a plethora of 'inside deaning' responsibilities ranging from student policies and curriculum review, faculty and staff hiring, [American Bar Association (ABA)] accreditation and standards compliance, admissions policy, oversight of the various departments of the law school, financial management, and the

5 "Law schools run like republics.... [T] he law school is governed by a chosen body of citizens - the faculty - who are ostensibly endowed with the wisdom to decide what is in the best interest of the institution and are able to put their personal interests to one side." Shauna Marshall, Rebellious Deaning: One African American Woman's Vision of a Progressive Law School, 24 CliniCAL L. REV. 135, 136 (2017) (footnote omitted).

6 Jeffrey O'Connell \& Thomas E. O'Connell, The Five Roles of the Law School Dean: Leader, Manager, Energizer, Envoy, Intellectual, 29 EMORY L.J. 605, 606 (1980).

7 Ronald F. Phillips, The Origins and Destinations of Law School Deans, 38 J. LEGAL EDUC. 331, 343 (1988).

8 John A. Miller, The Modern Law Dean, 50 J. Legal Educ. 398, 398 (2000) (discussing the role of fundraising).

9 Phillips, supra note 7, at 343.

10 Id.

11 Glen Weissenberger, A Letter to a New Dean, 39 U. ToL. L. ReV. 399, 399 (2008).

12 O'Connell \& O'Connell, supra note 6, at 605.

13 See id. at 609. 
like." 14 While faculty are able to focus on teaching and scholarship, a "law dean could easily spend all of his [or her] workday tending to the school's bureaucratic details and to developing the school's strategy for improvement." 15

\section{B. The Role of a Dean After the Great Recession}

Law school deans have always had to balance their jobs as academic and administrative leaders with fundraising expectations. ${ }^{16}$ But the recent recession's impact on legal education may have permanently changed the job of a dean. ${ }^{17}$

Economists labeled the 2007-09 worldwide economic downturn as the Great Recession. ${ }^{18}$ The recession "placed unprecedented stress on the legal profession," "19 as "[y]oung lawyers confronted a sudden, dramatic slowdown in hiring." 20 Because lawyers were not being hired upon graduation from law school, the number of matriculants in the fall of 2013 was the lowest since $1977 .^{21}$

Law school deans were suddenly confronted with immediate financial threat to their institutions, and some schools even faced closure. ${ }^{22}$ The

14 Jack M. Weiss, A Causerie on Selecting Law Deans in an Age of Entrepreneurial Deaning, 70 LA. L. REV. 923, 938 (2010).

15 Miller, supra note 8, at 402.

16 See Frank T. Read, The Unique Role of the Law School Dean in American Legal Education, 51 J. LEGAL EDUC. 389 (2001).

17 Even before the Great Recession, the challenges facing law schools included: the rising costs of legal education; excessive student-borrowing; the legal profession demanding changes in the curriculum; universities wanting more law school revenue; and faculties becoming increasingly "static" due to tenure and federal removal of retirement age. See id. at 390. These challenges have only increased since the Recession. See Daniel Thies, Rethinking Legal Education in Hard Times: The Recession, Practical Legal Education, and the New Job Market, 59 J. LeGAL EduC. 598, 599 (2010) ("The recession's effects - rising tuition, scarce student loans, and a poor job market - are pushing legal education to the breaking point.").

18 The Great Recession "last[ed] from December 2007 to June 2009," and "was the longest [recession] since World War II." Robert Rich, The Great Recession, FED. RES. HisT. (Nov. 22, 2013), https://www.federalreservehistory.org/essays/great_recession_of_200709.

19 Thies, supra note 17, at 599.

20 Weiss, supra note 14, at 933.

21 Ethan Bronner, Law Schools' Applications Fall as Costs Rise and Jobs Are Cut, N.Y. TimES (Jan. 30, 2013), https://www.nytimes.com/2013/01/31/education/law-schoolsapplications-fall-as-costs-rise-and-jobs-are-cut.html?hp\&_r=1\& (noting a thirty-eight percent decline in law school applications from 2010 to 2013); see also Jordan Weissmann, Law School Applications Are Collapsing (as They Should Be), ATLANTIC (Jan. 31, 2013), https://www.theatlantic.com/business/archive/2013/01/law-school-applications-are-

collapsing-as-they-should-be/272729 (explaining that the legal job market in 2013 was "crippled").

22 See Joyce E. McConnell, Getting a Job - Passing the Bar: Two Keys to a Career in the Law, W. VA. LAW., Jan.-Mar. 2010, at 16 ("Perhaps the most insidious effect of 
dean's job changed very quickly from requiring only the classic responsibilities - academic leadership, administrative responsibilities, and fundraising - to requiring innovative and quick-thinking leadership strong enough to carry a law school through difficult times, supplemented by a newly critical need to find jobs for the law school's graduates. ${ }^{23}$ Law schools now face new outside pressures, "rang[ing] from U.S. News rankings to the movement toward outcomes assessment; from the high cost of tuition to the shrinking number of high paying positions." 24 These new pressures and responsibilities have transformed the role of a law school dean, forcing deans to be more innovative.

\section{Law Deans as "Innovators"}

The effects of the Great Recession remain in legal education today. ${ }^{25}$ Law schools must therefore adapt quickly to a changing regulatory and economic environment, and deans must lead the charge. In fact, "any doubt about these [changes in a dean's role] has been swept away by the precipitous decline in state funding at many public law schools[,] and the near universal decline in law school and university endowments caused by the economic crisis." 26 Thus, in addition to their traditional responsibilities, today's law school deans must be seen as innovative change agents while defending their institutions. ${ }^{27}$ As the landscape of legal education shifts to a less stable market, a "dean's success or failure will turn on his or her ability to function as an entrepreneur." 28

This new "Age of Entrepreneurial Deaning" compels law deans (and law dean candidates) to think outside of the traditional law box in an effort to recruit applicants. ${ }^{29}$ Law schools are experimenting with new programs, degrees, and certificates. ${ }^{30}$ Some law schools are offering new weekend

the Great Recession is its erosion of student confidence in the choice to enter the legal profession."); see also Casey Sullivan, No Letup in Small Law School Closures Post Financial Crisis, Bloomberg L.: BIG L. Bus. (Mar. 26, 2018), https://biglawbusiness.com/no-letup-in-small-law-school-closures-post-financial-crisis.

23 See Robert Post, Reflection, Leadership in Educational Institutions: Reflections of a Law School Dean, 69 STAN. L. REV. 1817, 1820 (2017) ("It seemed that from every corner there arose insistent demands for more cost-effective legal education that would produce better-trained and accomplished lawyers.").

24 Nora V. Demleitner, Colliding or Coalescing: Leading a Faculty and an Administration in the Academic Enterprise, 42 U. ToL. L. REV. 605, 615 (2011) (footnote omitted).

25 See Sullivan, supra note 22.

26 Weiss, supra note 14 , at 924.

27 See id.

28 Id.

29 See id. at 923.

30 See, e.g., Hofstra Law to Host Legal Tech Bootcamp, Hofstra U.: LAwNews (Aug. 14, 2018), https://lawnews.hofstra.edu/2018/08/14/hofstra-law-to-host-legal-tech-boot- 
programs and "mixing online learning and in-class sessions to attract law degree seekers who want more flexibility." 31 In the wake of the Great Recession, law schools are looking for leaders who will be more willing to take risks in their efforts to attract applicants. ${ }^{32}$

Moreover, as wealthy alumni and foundations have become less able to provide support for law school initiatives, law school deans are now called upon to be innovative and imaginative in generating new sources of revenue from a wide variety of sources: individual private philanthropy, state and federal government, foundation grants, corporate gifts (and sponsorships), tuition increases, fee increases, school events, and even the creative use of the school's real estate (for instance, for parking or for use for private events). ${ }^{33}$

It is not just about raising revenue. Law school deans must also hold "a refined sense of when the law school should 'spend money to make money,' for example, on expensive brochures, paid advertisements, hired speakers, or costly web do-overs." ${ }^{34}$ Deans must understand the legal market enough to recognize what is required to make their law schools stand out in a crowded and competitive field.

\section{Law Deans as Job Placement Experts}

In this post-recession era, law school employment rates for graduates are more heavily scrutinized by applicants and by regulators. ${ }^{35}$ As part of its accreditation process for law schools, the $\mathrm{ABA}$ requires law schools to report detailed employment statistics. ${ }^{36}$ These statistics are also used for ranking purposes by organizations such as the U.S. News and World Report. ${ }^{37}$

camp/; see also Zach Warren, You Think Legal Education Can't Change? 8 Innovative Ideas from Law Schools, LEGALTECH NEws (Nov. 20, 2018), https://www.law.com/legaltechnews/2018/11/20/you-think-legal-education-cant-change-8innovative-ideas-from-law-schools/?slreturn $=20181028120657$.

31 Elizabeth Olson, The 2-Year Law Education Fails to Take Off, N.Y. TIMES: DEALBook (Dec. 25, 2015), https://www.nytimes.com/2015/12/26/business/dealbook/the-2-year-laweducation-fails-to-take-off.html.

32 See id.

33 Weiss, supra note 14 , at 932

34 Id.

35 See id. at 933 ("[T]he economic crisis of 2008-09 put to rest any notion that law schools and law deans could largely ignore" the issue of graduate employment).

36 See Jill Backer, Law School Employment Data Reporting: Are We Losing the Forest for the Trees?, N.Y.L.J. (Mar. 19, 2018), https://www.law.com/newyorklawjournal/2018/03/ 19/law-school-employment-data-reporting-are-we-losing-the-forest-for-the-trees ("The ABA asks for many points of data to be collected on each graduating student. They even require notes on when, how and by whom each point of data is acquired. This means hundreds of hours a year are spent by career centers acquiring and entering such data.").

37 See id. 
Before the Great Recession, deans in many law schools, especially highly ranked law schools, were able to delegate job placement to their career service offices. Stable attorney jobs, including government jobs and partner-track associate positions at large law firms, decreased during the recession and show no sign of returning to their pre-recession levels. ${ }^{38}$ Instead, many lawyers now perform contract work as part of a "gig" economy, or find work in so-called "J.D. advantage" jobs in which a law degree is helpful but not necessary. ${ }^{39}$

Thus, a law dean "must become not only fundraiser-in-chief, but placement-officer-in-chief, building on his or her interactions with alumni and other law school constituents to actively promote the hiring of the school's graduates." 40 The ability to recognize trends in the local legal market and place graduates into full-time employment is now a critical part of the job, and dean search committees now focus substantial attention on these matters when reviewing dean candidates. ${ }^{41}$

\section{The Dean as a "Juggler" of Various Constituencies}

Law school deans "must serve a larger and more diverse constituent base" than anyone else in the institution. ${ }^{42}$ Law deans are responsible for answering the needs of "management boards, central university administrations, alumni, corporate donors, state legislative and executive officials, faculty, and even students, who understandably keep a keen eye on how the law school is 'pricing' the service of legal education." 43 These various constituencies often have competing interests, and it is the job of a dean to "somehow harmonize" conflicts when they arise among these groups. ${ }^{44}$

38 See Rick Ruggles, Law Schools May Be on Post-Recession Rebound, but Job Market is Still Tight, OMAHA WorLd-Herald (Mar. 14, 2017), https:/www.omaha.com/news/ education/law-schools-may-be-on-post-recession-rebound-but-job/article 609721b2-3626523c-9124-fa51020cacf8.html ("[T]here can be little confidence that it (the job market) will return to what it was before the recession.").

39 Marilyn Odendahl, A Growing Advantage to the Law School Degree, IND. LAw. (Nov. 4, 2015), https://www.theindianalawyer.com/articles/38614-a-growing-advantage-to-the-law -school-degree.

40 Weiss, supra note 14, at 934 (citing Kent D. Syverud, Dean, Wash. Univ. Sch. of Law, Remarks at the Association of American Law Schools 2010 Annual Meeting, Session for the Law School Dean (Jan. 7, 2010) ("[T]he deep and likely continuing turmoil in the legal job market has made placement of our graduates an absolutely critical priority for law schools and their deans.").

41 In the author's experience chairing two dean searches at Golden Gate University School of Law, this element was an integral part of the interview process.

42 Read, supra note 16, at 389.

43 Weiss, supra note 14, at 931; see also Kevin R. Johnson, The Forgotten Constituency? Law School Deans and Students, 42 U. ToL. L. REV. 637, 637 (2011).

44 Robert Gilbert Johnston, What is a Dean For?, 35 U. ToL. L. REv. 111, 115 (2003). 
A strong dean must be able to navigate large challenges in addition to mediating smaller conflicts as they arise. These larger trials may include financial challenges, such as a university taking more than its share from law school revenues, ${ }^{45}$ organizational challenges, including university staff or alumni who wish to intrude on law school initiatives; internal conflicts with faculty who have strongly-held but divergent ideas about faculty governance; ${ }^{46}$ and political challenges for public law schools facing threatening regulation. ${ }^{47}$ Outstanding communication skills are therefore a prerequisite for the job, since "the dean is the person who translates the realities of modern legal education for the school's alumni [and university administrators,] and, correspondingly, explains the challenges and needs of the legal profession to the faculty." 48

Deans were always in the position of needing to understand and address the needs of their various constituencies. But the increasing outside pressures facing law schools after the Great Recession mean that deans today must respond to challenges more quickly and imaginatively than in the past. ${ }^{49}$ The results are not always successful, leading one academic to note that "the supposedly high-and-mighty dean, has slowly devolved from the classic stereotype of a benign autocrat to, in too many cases, little more than an embattled, dispirited juggler trying to accommodate increasingly fractious constituencies." 50

If it is true that deans are now "embattled, dispirited juggler[s],"51 this has profound consequences for law dean search committees. As difficult as the "juggling" may be, it must be recognized that deans hold an extraordinary amount of power, both inside and outside of their institutions. Indeed, "[d]eans have incredible discretion and can do a large amount of good, but

45 Read, supra note 16 , at 393.

Too frequently, the central administration views the dean as little more than a middle manager whose duty it is to carry out its commands. Contrast this with the faculty view that the dean is little more than a managing partner of their college, whose duty is to fight for the view of the faculty against the central administration.

Id.

46 See id. at 391 ("The lines between what have traditionally been thought to be decanal powers and what have been thought to be faculty academic powers have blurred. Faculty, more and more, want to be consulted about everything.").

47 See Weiss, supra note 14, at 938.

48 R. Lawrence Dessem, Maybe Deaning Is Not for You, 39 U. ToL. L. REV. 261, 266 ("The law school dean not only communicates with various law school constituencies, but is the individual who facilitates communication among these constituencies.").

49 See Read, supra note 16, at 390 ("[M] ore responsibilities than ever are being conferred upon the dean.").

50 Id.

51 Id. at 390, 395 ("The dean has to juggle multiple constituencies all viewing the role of the dean in different ways, without dropping too many of the balls at one time."). 
they also can do some bad." ${ }^{, 5}$ During this challenging time in legal education, it is the responsibility of dean search committees to find visionaries who can lead a law school in innovative ways, while honing the ability to work with groups of people holding widely disparate viewpoints. ${ }^{53}$ Deans who are unable or unwilling to recognize the changing landscape of the legal profession and to balance conflicting ideas will simply not succeed in the role.

Accordingly, dean search committees should select deans from a diverse pool of candidates, and that pool should reflect the increasing diversity in law schools and in the legal profession. ${ }^{54}$ As discussed below, however, the available statistics analyzing diversity among deans demonstrate that many dean search committees are fishing in the same ponds. Especially given the unusual discretion and power inherent in the dean's role, dean search committees must ensure that their institutional and personal biases do not impact the dean search process.

\section{The TyPICAL DeAn SEARCh Process AND DIVERSITY of DEANS}

Anyone who has ever been part of a dean search process would agree that it is "long and arduous, especially for the candidates," and can be "an extremely political process." 55 This section will first outline the typical dean search process for American law schools, and then it will assess whether dean search committees are effectively selecting diverse candidates to be law school deans.

Most dean search committees are looking for the same type of dean: "[v]irtually everyone wants a skilled administrator, a great and proven fundraiser, a super-star scholar (the most frequently sacrificed aspiration in a dean), a leader committed to his or her institution, and much more[,]" including a dean who will increase the ranking of the school. ${ }^{56}$ Committees should also consider finding deans who understand the law school's mission and pedagogical approach. Although every law school can create its own individualized search process to find this magical dean, all law schools are subject to the regulations of the ABA.

52 Kevin R. Johnson, Commentary, Session 1: Deciding to Become a Dean, 31 SEATTLE U. L. REV. 813, 814 (2008).

53 See Read, supra note 16, at 396 ("[O]verriding it all is the need to be the visionary leader who can convince all the constituencies of the need to move in the same direction at the same time.").

54 See infra Part III.C for diversity statistics.

55 Johnson, supra note 52, at 814.

$56 I d$. at 815,816 ("In essence, every school basically wants a dean who can walk on water."). 


\section{A. ABA Requirements}

The U.S. Department of Education delegated regulating authority over law schools to the Accreditation Committee and the Council of the ABA Section of Legal Education and Admissions to the Bar (the "Council"). ${ }^{57}$ The Council regularly drafts the Standards and Rules of Procedure for Approval of Law Schools (the "Standards,") which govern the operation of law schools; these standards are meant to "establish requirements for providing a sound program of legal education." 58 A law school's ABA accreditation depends upon compliance with these Standards. ${ }^{59}$

The Council's Standards guide the process for appointing a law school dean in ABA-accredited law schools. "[D]ean[s] shall be selected by the university or the governing board of the law school . ..."60 The process for a dean's appointment or reappointment must assure "meaningful involvement by the faculty or a representative body of the faculty in the selection of a dean." ${ }^{61}$ Faculty, therefore, play a critical role in choosing a dean; although the ultimate selection is made by a university or its board members, "a dean should not be appointed or reappointed to a new term over the stated objection of a substantial majority of the faculty" without good cause. ${ }^{62}$ Law schools in the United States also belong to other organizations, each of which has its own governing procedures for members. ${ }^{63}$ For

57 See Am. Bar Ass'n, Section of Legal Educ. \& Admissions to the Bar, The Law School ACCREditation Process 3 (2016) [hereinafter AM. BAR Ass'N, ACCREDitation PROCESS], https://www.americanbar.org/content/ dam/aba/publications/misc/legal education/2016 accreditation

brochure final.authcheckdam.pdf; see also 34 C.F.R. § 602.1 (2018).

58 Am. BAR ASs'N, ACCREDitation Process, supra note 57, at 3.

59 See id. at 3, 8-9.

60 Am. BAr Ass'n, Section of Legal Educ. \& Admissions to the Bar, ABA StANDARDS AND RULES OF Procedure FOR APPROVAL OF LAW SCHOOLS, Standard 203 (20182019) [hereinafter AM. BAR ASs'N, STANDARDS AND RULES OF PROCEDURE], https://www.americanbar.org/content/dam/aba/publications/misc/legal_education/ Standards /2018-2019ABAStandardsforApprovalofLawSchools/2018-2019-aba-standards-rulesapproval-law-schools-final.pdf.

61 Id.; see also Eric J. Gouvin, Looking for a Leader: A Primer for the Dean Search Committee Chair 3 (Oct. 2002), https://papers.ssrn.com/sol3/papers.cfm?abstract_id=197543 9 [hereinafter Gouvin, Looking for a Leader] ("As our faculty [at Western New England School of Law] understands the ABA Standards, the search committee must be accountable to the faculty through substantial faculty participation. We achieved that goal through having four faculty members on a nine-person committee.").

62 AM. BAR ASs'N, STANDARDS AND RULES OF PROCEDURE, supra note 60, Interpretation 203-1.

63 See Patrick H. Gaughan, Facilitating Meaningful Change Within U.S. Law Schools, 16 U.N.H. L. REV. 243, 257 (2018).

[T] $]$ he $\mathrm{ABA}]$ Council has a network of affiliate organizations/institutions to which most U.S. law schools belong. These include: The Association of American of Law Schools (AALS); Clinical Legal Education 
example, the American Association of Law Schools' (AALS) Bylaws also provide that the faculty's involvement is an important part of the dean selection process. The Bylaws state that a faculty shall have "meaningful involvement" and must be consulted "individually or collectively" regarding a dean's selection. ${ }^{64}$ Similar to the ABA's Standards, the AALS Bylaws provide that no dean should be appointed if there is "expressed opposition of the faculty (acting as a whole or by a representative portion determined by reasonable criteria)." 65

Every ABA accredited law school must construct a dean search process in compliance with these Standards and Bylaws. As a result, a law school's dean search process typically includes a great deal of faculty involvement.

\section{B. The Typical Dean Search Process}

While every law school may employ a slightly varied dean search process, this section will explain the typical steps that law schools take to find a dean.

\section{The Players: Creating a Dean Search Committee}

Every person working in a law school is impacted by a dean search. Indeed, the best way to get the immediate attention of participants in any law school meeting is to begin with the words, "[h]ere is what is happening with the dean search."

Consequently, "all important law school constituents" should have representation on a dean search committee. ${ }^{67}$ These typically include not just members of the law faculty, but also law school administration, board of trustee members, university administrators, alumni, and/or faculty from other schools within the university. ${ }^{68}$ Committee members must be sensitive to the fact that "each constituency in a law school has a different fear about

Association (CLEA); Law School Admission Council (LSAC); National Association of Law Placement (NALP); and National Conference of Bar Examiners (NCBE). Even if these institutions do not have express regulatory power over U.S. law schools, they still play important normative roles.

Id. Law schools and universities are also subject to regional accreditation. See How Institutions Are Accredited, HIGHER LEARNING COMMISSION, https://www.hlcommission.org/ Student-Resources/how-institutions-are-accredited.html (last visited Oct. 26, 2018).

64 AALS Handbook: Bylaws, § 6-5, Ass'N AM. L. SCH., https://www.aals.org/about/hand book/bylaws/ (last visited Feb. 5, 2019) [hereinafter AALS Handbook: Bylaws].

65 Id.

66 This is based on the author's experience chairing two dean searches at Golden Gate University School of Law.

67 Gouvin, Looking for a Leader, supra note 61, at 3.

68 See id. at 3-4. 
a new dean and thus looks for something different in the dean candidates." ${ }^{\prime 69}$ For example, faculty members are usually concerned about salaries, class assignments, research stipends, and the school's scholarly direction. ${ }^{70}$ Staff members lack tenure, and are therefore apprehensive about losing their jobs or becoming inundated with work by a new dean. ${ }^{71}$ "Students and alumni have their own sets of interests and concerns, which are incredibly important to them, but considerably less important to the faculty and staff." "72 Dean search committees may find it difficult to adequately address the concerns of all constituents during the search process, but they should start by ensuring that the choice of committee members reflects "the interest that various constituencies have in the outcome."73

Furthermore, the composition of a dean search committee should reflect racial, gender, and other types of diversity. In fact, certain types of implicit bias may be revealed in the selection of members for these important committee roles. ${ }^{74}$ For example, a recent dean search committee chair explained that "because the committee appointment process focused so much on insuring representation of various functional groups [i.e., constituents within the university], we were not sensitive enough to making sure that the committee reflected the diverse demographic aspects of the law school community." 75 As a result, although they had gender parity and "representation of [the] gay and lesbian community, ... there were no people of color on the committee." 76 University leadership and search committees should prioritize diversity when naming members to committee chairs, since "[a] diverse committee will help ... recruitment efforts reach all qualified applicants." 77 In addition, a diverse committee will likely ensure more buyin from faculty when dean candidates are presented, and can lead to broader confidence in the final hire.

9 See Johnson, supra note 52, at 814.

See id.

See id.

Id. at $815-16$.

Theodore J. Marchese \& Jane Fiori Lawrence, The Search Committee HANDBOOK: A GUIDE TO RECRUITING ADMINISTRATORS 13 (2d ed. 2005).

74 See infra Part IV for a detailed description of implicit bias.

75 Gouvin, Looking for a Leader, supra note 61, at 4 (emphasis in original).

76 Id.

77 Id. at 5. For a good list of questions to ask when appointing committee chairs, see MARCHESE \& LAWRENCE, supra note 73, at 13 ("Does [the committee] reflect diversity by gender and race? [T] he interest of nontenured faculty? Does it include champions for affirmative action goals?"). 
2. The Process: One Step at a Time

\section{i. Timing}

Once the dean search committee is established, the next step is to determine the timing of the search process. For example, when the author became chair of her law school's dean search committee in February 2017, the university president asked the committee to work to find a dean before the start of the new academic year in August. Fortunately, the dean at that time indicated that she would be willing to continue to serve as dean if the committee was unable to find a suitable candidate before August. With the flexibility of that standby plan in place, the committee worked on an accelerated schedule. It hired a new dean in May, and he began his term in July 2017. Thus, depending on the needs of the school, a committee might decide to expedite or delay the process.

It is generally advisable not to delay a dean search process too long. ${ }^{78}$ It can be difficult for members of the law school community to work effectively while dealing with leadership uncertainty, and a committee also risks losing candidates to schools that are conducting more efficient dean searches. A committee moving too quickly, however, might not effectively include input from all constituencies within the law school. Moreover, although it can be efficient to select a dean already known to the community, such as an internal candidate, it takes time to create a diverse pool of dean candidates.

\section{ii. Crafting the Job Description: the "Listening Tour"}

With the timing of the search determined, a search committee should move forward with the creation and posting of a job description. A "listening tour" to solicit input from the law school community is an essential part of this process. ${ }^{79}$ During the author's first dean search in 2012, the committee wrote a job description over the summer (with the assistance of the Director of Human Resources), and the author then conducted a listening tour when the term began in August. Several community members were surprised to learn in August that the job description had already been drafted and publicized.

During the 2017 dean search, our university president asked the committee to conduct a listening tour and solicit input before the committee wrote a job description. Upon reflection, the author realized that this is an

78 See Gouvin, Looking for a Leader, supra note 61, at 2 ("[I]f you are getting a very late start [on your dean search,] you ought to consider whether it would make more sense to appoint an interim dean and conduct your search in the next cycle.").

79 See id. at 6 (explaining that it is critical "to think about who should have input into the selection process and how the committee will gather than input"). 
excellent way to ensure diversity of thought in the job description. To gather input, the author held numerous "Town Halls" for faculty and students, and attended an all-staff meeting to ask for input. In each of these meetings, the author reassured community members that their comments and suggestions would remain confidential.

Because some people may have felt uncomfortable sharing opinions on this important topic in front of colleagues, the author also offered her e-mail address to everyone in the law school and invited confidential e-mail comments. Numerous faculty, staff, and students took her up on this e-mail invitation. These comments were invaluable, and several of them ultimately influenced the drafting of the job description. In addition, with the help of the Student Bar Association, the dean search committee created an online survey to enable students to offer anonymous feedback to the committee. The efforts spent seeking community input were well spent, for the committee received widespread buy-in when the dean finalists were selected.

Dean search committees in other schools have used different ways to solicit community input, with varying degrees of success. During a 1973 dean search, the chairs of the dean search committee "held an open meeting to discuss the criteria for dean selection." ${ }^{80}$ The committee publicized the meeting, and encouraged the faculty and student attendees to present their views about the qualities needed in a new dean. After the meeting, the dean search committee members determined that the results were disappointing, since faculty members did not offer opinions and the students did not consider the full range of issues facing a new dean. ${ }^{81}$ Later feedback revealed "at least limited student belief that the ... public meeting was a charade, rather than a serious attempt to solicit opinions." ${ }^{" 82}$

Professor Eric Gouvin, in his detailed assessment of a dean search at Western New England School of Law, recognized after the search was completed that "support staff felt shut out of the whole process." Gouvin concluded that "putting together a process that did not give them some voice was a terrible oversight." wide variety of groups within the law school does more than create credibility for the dean search committee-it can also reveal fractures within the law school community and motivate committee members to give weight to a wide range of opinions.

80 Herbert I. Lazerow \& John M. Winters, In Quest of a Dean, 26 J. LEGAL EdUC. 59, 63 (1973).

1 See id.

82 Id.

83 Gouvin, Looking for a Leader, supra note 61, at 6.

84 Id. 


\section{iii. Advertising the Dean Position}

Once the listening tour and job description are complete, the next step is publicizing the job description. This requires marketing and networking skills, and can be a "frustrating and time-consuming part of the [dean] search [process]." ${ }^{.85}$ Asking the law school faculty and staff to share the job description with their contacts can be a "very fruitful" way to develop a pool of candidates. ${ }^{86}$ This is likely, however, to allow the faculty's biases to influence which friends and colleagues see the job posting. ${ }^{87}$ The same is true for posting the job description on faculty listservs, which is an effective way to spread the word, but is also limited to a closed network.

Advertising in a wide array of publications is another way to increase the diversity of applicants. For example, one recent committee advertised in the Chronicle of Higher Education, Black Issues in Higher Education, Hispanic Outlook in Higher Education, AALS Recruitment Bulletin, and bar newspapers in the region. ${ }^{88}$ Although the committee must consider advertising to the audiences who will have interest, ${ }^{89}$ dean search committees "should give special consideration to techniques for developing interest in [the dean] position among persons of color and women." 90 Broader advertising may lead to a broader pool of candidates.

\section{iv. Review of Applications}

As applications begin to roll in, the next step for the committee is the initial review of applications. At this stage, committee members should first take a step back to make sure that their publicizing efforts created a pool of diverse candidates. A human resources director or the committee chair could do this with a "census," allowing a committee to ask whether the candidate pool is satisfactorily diverse. ${ }^{91}$ This step enables the committee members to confirm that implicit biases did not interfere with the advertising of the position; that is, if a diverse pool of candidates does not exist at this point, the committee should re-double its advertising efforts to attract different candidates.

Once the pool is deemed acceptable, the committee must review applications. This requires committee members to "cull through what seem[s] like daunting piles of application materials to locate candidates of

85 Lazerow \& Winters, supra note 80, at 64.

86 Gouvin, Looking for a Leader, supra note 61, at 19.

87 See infra Part IV.C for a discussion of in-group favoritism.

88 See Gouvin, Looking for a Leader, supra note 61, at 24-25.

89 See id.

90 Id. at 26.

91 MARCHESE \& LAWRENCE, supra note 73, at 51. 
highest promise." $" 92$ Committee members should recognize that implicit biases could influence this resume review process. ${ }^{93}$

Search committees should therefore "watch [their] mindset," since the "psychology of elimination" might encourage a committee member to "look for any excuse to get rid of someone." 94 It is at this point "that mistakes are made, that the nontraditional or unusual candidacy is lost," and "may be why some women or minority candidates get lost."

By recognizing the role that implicit bias can play in the review of application materials, dean search committee members should be able to employ the "right mindset" of "talent hunting." 96 Screening requires committee members to look for interesting, even alternative, candidates who might bring something new and exciting to the dean role. ${ }^{97}$

\section{v. Screening Interviews}

Once the committee removes candidates who are clearly unqualified or otherwise unfit to move forward, the next stage is the initial screening interviews. These sixty- to ninety-minute interviews were traditionally done via telephone or short in-person meetings. ${ }^{98}$ In the modern era, however, these interviews can be easily completed via videoconference. ${ }^{99}$

Depending on how many candidates emerge as viable options from the initial screening interviews, a second set of (longer) screening interviews may be required. For both initial and follow-up screening interviews, the committee should take great care in crafting specific questions for every candidate, based on the issues already identified through the listening tour. These questions may be "designed to sound out the candidates on a range of topics, but [are usually] geared toward finding out why [this] particular law

92 Id. at 13.

93 See generally Marianne Bertrand \& Sendhil Mullainathan, Are Emily and Greg More Employable than Lakisha and Jamal? A Field Experiment on Labor Market Discrimination, 94 Am. ECON. REV. 991 (2004); see also infra Part IV.E.

94 MARCHESE \& LAWRENCE, supra note 73, at 52-53.

95 Id. at 53.

96 Id.

97 See Gouvin, Looking for a Leader, supra note 61, at 27-29 (providing a detailed example of this screening process).

98 See Laura M. Padilla, A Gendered Update on Women Law Deans: Who, Where, Why, and Why Not?, 15 Am. U. J. Gender Soc. PoL'y \& L. 443, 454-55 (2007). For example, Western New England School of Law's dean search committee conducted a "centralized national interview" at Chicago's O'Hare Airport in 2000. See Gouvin, Looking for a Leader, supra note 61 , at 29.

99 See, for example, Golden Gate University School of Law's use of Zoom for its initial screening interviews in 2017 - even for local candidates - to ensure that every candidate was screened by the same method. Zoom proved to be a simple and effective interview technique. See ZoOM VIDEO COMM., https://zoom.us/ (last visited Oct. 17, 2018). 
school would be a good place for this particular candidate to be a dean."100 The committee should double-check questions to ensure implicit bias is not present.

Committee members will likely also have unique questions for specific candidates, including asking for explanation of unusual career paths, time gaps in resumes, or other issues. Keeping in mind that bias can play a role during these interviews, committee members must take care to refrain from posing questions that are illegal to ask in the employment context. ${ }^{101}$

This is not to suggest that issues of diversity cannot be a topic during dean search screening interviews. Committees should use interview questions to learn how each candidate would approach the particular issues facing that institution. For example, participants in a recent conference focused on "Promoting Diversity in Law School Leadership" reviewed sample interview questions for this type of interview. ${ }^{102}$ These included typical questions, such as "[w]hat is your vision for this position and the school?" and "[w]hat is your management style?"103 They also included diversity-minded questions: "How would you address the campus environment of protest around race equity?"104

After each screening interview, it is a good idea to give the committee a few minutes to discuss initial impressions of candidates. At this stage, committee members may find that they are in agreement of their assessments of candidates, or they may hold widely divergent viewpoints. Either way, this is not the forum for finalizing a decision. It is often useful, however, to learn whether a particular comment or question during an interview was interpreted differently among the committee members. This is also a good way to consider whether any biases or "hidden screens" were at work during an interview, since, in the author's experience, committee members are much less likely to hold back initial impressions immediately after an interview. ${ }^{105}$

100 Gouvin, Looking for a Leader, supra note 61, at 29-30.

101 MARCHESE \& LAWRENCE, supra note 73, at 58 ("Prohibited questions can vary by state and institutional policy but they typically proscribe asking, even indirectly, about a candidate's age, race, color, disability, marital status, nationality, ethnic origin and the like.").

102 See Univ. of WASH. Sch. OF LAW, Promoting DiVERSITY In LAW SCHOOL LEADERShIP CONFERENCE: SAMPLE INTERVIEW QUESTIONS (2016), https://perma.cc/LJB8-2PFX.

103 Id.

104 Id.

105 MARCHESE \& LAWRENCE, supra note 73, at 54 (discussing "hidden screens" in the context of reviewing candidates who are unlikely to move forward in the process). Even a ten minute "debriefing" after each interview "can ensure that you capture important findings and reactions from the group." Id. at 73 . 
vi. Selecting Finalists, Reference Checks, and the On-Campus Visit

Once the screening interviews are concluded, each committee member should have time to evaluate individual candidates - and the pool as a whole - to identify finalists. Some committees do this through a rating system. $^{106}$ Depending on the number of candidates, a committee may prepare a notebook for consideration. ${ }^{107}$ Note that the use of photographs in the notebook may be problematic, since implicit bias research shows that committee members may be more influenced by images of race and gender than they realize. ${ }^{108}$

Depending on the size of the pool, some committees may begin reference checks at this stage. They may then use the reference check results in the determination of finalists. ${ }^{109}$ Others may choose finalists first, and then commence reference checks. A "modest but useful guard against bias" in checking references is to "assign calls about each candidate to different committee members," rather than asking one committee member to make all calls about a particular candidate. ${ }^{110}$ In this way, committee members learn about each candidate from different angles. This would also prevent a reference checker from "falling in love with a candidate on the first call" and then hearing from subsequent references only information that confirms the first positive impression. ${ }^{111}$ The idea is to ensure that each committee member reports his or her reference check results to the rest of the committee as a "reporter or analyst," not "as an advocate."112

Law schools differ at this stage regarding how they handle candidates' desire for secrecy. It is common for candidates to refrain from alerting their home institutions that they are seeking a dean position elsewhere, since "candidates [do not] want to be known that they are being considered in case they [are not] chosen ... which would damage their reputation in other searches, or at their home institutions." 113 Public schools generally post the

106 See, e.g., Gouvin, Looking for a Leader, supra note 61, at 33 ("In order for the candidate to be invited back to campus, the candidate had to receive the unanimous support of the four members of the faculty subcommittee that did the screening interviews and also had to receive support from the committee as a whole, although not unanimously."); see also MARCHESE \& LAWRENCE, supra note 73, at 53-54.

107 See, e.g., Gouvin, Looking for a Leader, supra note 61, at 31.

108 See Mark W. Bennett, The Implicit Racial Bias in Sentencing: The Next Frontier, 126 YALE L.J.F. 391, 404 (2017) ("The photograph is a classic psychological prime that can easily trigger implicit bias in the judges' evaluation of the rest of the pre-sentence report.").

109 See MARCHESE \& LAWRENCE, supra note 73, at 60.

110 Id. at 59.

111 Id.

112 Id

113 E-mail from Deborah Rhode, Professor of Law, Stanford Law Sch., to Michele Benedetto Neitz, Professor of Law, Golden Gate Univ. Sch. of Law (July 31, 2018, 3:11 PM) [hereinafter E-mail from Deborah Rhode] (on file with author). 
finalists' identities and resumes before the final choice is made, but private schools may keep the finalists' names secret from everyone except dean search committee members.

Regardless of the way schools handle candidate privacy, "it is typical for a search committee to winnow the list [after screening interviews] to five or six candidates who are invited to campus for a more extensive interview." "114 The on-campus visit, which usually lasts at least one and a half to two days, "normally requires the candidate to meet with the law school's various constituencies and key persons in the central administration." 115 These include "one-on-one meetings" with associate deans, the university president, trustees, and possibly alumni. ${ }^{116}$ The visit will also include presentations, or "job talks," to faculty and staff, and students may be included. ${ }^{117}$ Candidates will generally attend at least one dinner at a fancy restaurant with faculty and/or university leadership; the dinner "may be an opportunity to make a good impression on the candidates by taking them to especially nice places in the local area."118 Dean search committees should be as careful as candidates to make a good impression during the on-campus visit, since a strong dean candidate may withdraw if she does not feel favorably about the law school during the visit. ${ }^{119}$

\section{vii. Extending an Offer}

When all of the on-campus interviews are completed, "the narrowing process continues." 120 The faculty will usually convene to discuss the candidates, which may include a faculty vote to rank the final candidates. ${ }^{121}$ In some schools, "if the faculty comes to an agreement, the school will extend an offer to its first choice, perhaps reserving a back up candidate who

114 Padilla, supra note 98, at 455 (alteration in original omitted) (quoting Robert H. Jerry, II, A Primer for the First-Time Law Dean Candidate, 49 J. Legal EdUC. 564, 572 (1999)).

115 Id.; see R. Lawrence Dessem, Unsolicited Advice to Law School Dean Search Committees, 34 U. Tol. L. REv. 55, 61 (2002) [hereinafter Dessem, Unsolicited Advice] ("These two-to-three-day visits are very intense for candidate and search committees alike.").

116 Gouvin, Looking for a Leader, supra note 61, at 38-43 (providing a detailed description of the itinerary for a campus visit for dean candidates).

117 See Padilla, supra note 98, at 455.

118 Gouvin, Looking for a Leader, supra note 61, at 41.

119 See Dessem, Unsolicited Advice, supra note 115, at 61 ("Candidates may lose interest in the law school due to staff member or student comments about the city in which the law school is located, the local weather, or other matters not directly pertaining to the law school.").

120 Padilla, supra note 98 , at 455.

121 For a detailed description of this ranking process, see Gouvin, Looking for a Leader, supra note 61, at 44-45. But see MARCHESE \& LAWRENCE, supra note 73, at 59 (Ranking is not recommended because it "constrains the appointment officer's choice" and "tends to force the evidence and distort a report"). 
is also acceptable." 122 In other schools, the president or provost technically makes the final choice "with the advice of the search committee, passing along the preferences of the faculty as additional information." 123 Thus, although law schools must take care to follow the ABA mandate requiring faculty to have "meaningful involvement" in the selection of a dean, ${ }^{124}$ the ultimate decision-making process for each school may vary widely. ${ }^{125}$ In fact, the final "selection process may be firmly in the control of the faculty or firmly in control of the administration." "126

Once the final choice is determined, the president (or provost) will contact the chosen candidate. ${ }^{127}$ In line with the strategies discussed in Part $\mathrm{V}$ of this Article, presidents and provosts should ensure that implicit bias is not an issue during hiring negotiations. The dean search chair or the president will also contact the finalists who were not selected; if time allows, a personal note to candidates thanking them for their interest in the law school is a good idea. ${ }^{128}$ After all, depending on the outcome of this dean search, the next dean search may be only a few years away.

\section{Search firms}

In light of the detailed process described above, it is not surprising that many law schools choose to engage a search firm or search consultant to assist a dean search committee with this process. ${ }^{129}$ Search firms are becoming an increasingly important part of searches for university administration positions, and they are "taking root in the law school world." " School of Law hired a search firm to facilitate its 2016 law school dean search. ${ }^{131}$

122 Padilla, supra note 98 , at 455.

123 Gouvin, Looking for a Leader, supra note 61, at 43 (explaining the 2000 dean search process at Western New England School of Law).

124 Am. BAR Ass'N, StANDARdS AND RULES OF Procedure, supra note 60, Standard 203 (discussion of the ABA requirements).

125 Eric J. Gouvin, Register This! Searching for a Better Way to Search for Law Deans. . ., JURIST (Oct. 24, 2002), http://www.law.jurist.org/forum/forumnew64.php [hereinafter Gouvin, Register This!] ("While the steps in the [dean search] process may be broadly similar, the details vary widely from school to school.").

126 Gouvin, Looking for a Leader, supra note 61, at 43.

127 The president of Golden Gate University contacted the chosen dean candidates directly in 2012 and 2017. This information is based on the author's experience as the chair of those dean searches. See also MARChESE \& LAWREnCE, supra note 73, at 48 (provost called the first-choice candidate).

128 Id. at 80.

129 See Dessem, Unsolicited Advice, supra note 115, at 57.

130 Weiss, supra note 14 , at 932.

131 Berkeley Law hired search firm Isaacson Miller for its 2016 law dean search. See Dean Search Survey, BERKELEY L. NEwSL., https://myemail.constantcontact.com/Reunion- 
The use of a search firm can serve as a hot topic for a dean search committee. ${ }^{132}$ Creating a reasonable group of viable candidates for a dean position is difficult; if the dean search committee members do not have the time or contacts to advertise broadly as described above, a search firm "may do a good job of systematically building the candidate pool."133 In addition, a search firm could "attract candidates who might not want their current institution to know about their application." By engaging a search firm, "universities are able to keep that information [which would normally be public record] out of the public eye." 134 One recently hired dean believed that the search firm made the "process clearer for someone like me without inside knowledge" of the law school. ${ }^{135}$

The costs of hiring a search firm, however, can be exorbitant. Search firms "typically charge a fee equivalent to one-third of the hire's first year salary," along with other administrative costs such as advertising and travel. ${ }^{136}$ For example, in 2014, the University of Florida School of Law hired a search firm to find a law school dean after its original $\$ 90,000$ search failed. ${ }^{137}$ The University of Cincinnati "paid two firms $\$ 118,834$ to find a dean for its law school in 2014." 138 Moreover, because search consultants have traditionally not been engaged in law school dean searches, "few search firms have experience with legal education." "139 Consequently, universities and law schools may pay extremely high costs for search firms, while the dean search committees continue to do the heavy lifting. ${ }^{140}$ This dynamic

recap - dean-search - new-students - faculty-Deal-Camp-

more.html?soid=1101913634762\&aid=teOL9o26k_4 (last visited Nov. 28, 2018).

132 This is based on the author's experience chairing two dean searches. For example, during the 2017 Golden Gate University School of Law dean search, several members of the board of trustees believed a search firm was a worthwhile investment. Most law faculty members of the committee preferred to do the heavy lifting themselves without engaging a search firm. The committee ultimately decided to conduct the dean search without a search firm with the understanding that a search firm may be appropriate if the dean search failed in its first round.

133 Dessem, Unsolicited Advice, supra note 115, at 57.

134 Lance Lambert, Millions Paid to Find University Talent, Dayton Daily News, https://www.mydaytondailynews.com/news/state - regional-govt - politics/millions-paidfind-university-talent/G53PtMrE3aqLjaCZDwExKJ/ (last updated Jan. 17, 2016).

135 Telephone Interview with Anonymous Dean 1 (July 9, 2018).

136 Lambert, supra note 134.

137 Beatrice Dupuy, New Law Dean Search Will Cost UF \$100K, InDEP. FlA. ALLIGATOR (Dec. 8, 2014), https://www.alligator.org/news/uf administration/new-law-dean-search-willcost-uf-k/article_143dadf4-7e9d-11e4-8566-1bc236aa69a3.html.

138 Lambert, supra note 134.

139 Dessem, Unsolicited Advice, supra note 115, at 57.

140 For an illustrative example of the pro/con debate over the use of search firms in law school dean searches, see Jacqueline Lipton, To Search (Firm) or Not to Search (Firm)?, FACULTY LOUNGE (Apr. 22, 2011, 4:52 PM), http://www.thefacultylounge.org/2011/04/tosearch-firm-or-not-to-search-firm.html. For instance, compare comments in favor of search 
prompted one former university president to ask "why searches cost so much, why presidential [and dean] candidates are predictably recycled, [and] why briefs and job descriptions seldom match the rich diversity of institutions and missions in American higher education." ${ }^{141}$ Notably, the state of Illinois passed legislation in 2012 prohibiting public institutions from hiring search firms. ${ }^{142}$

Thus, the hiring of a search firm is not always a suitable step for a dean search committee to take. Whether a university will engage a search firm for a law school dean search will depend on numerous factors, including the size of the law school, its budget, its prior history with dean searches, the inclinations of the trustees and university leadership, and the opinions of the members of the dean search committee.

\section{Who Becomes a Dean in American Law Schools? Decanal Diversity}

In light of the critical role of a dean in a law school, and the burdensome process for selecting one, the obvious next question is: who are actually being hired as deans? Statistics demonstrate that candidates selected to be deans in American law schools are not yet diverse in terms of gender, race, sexual orientation, and socioeconomic status. Before reviewing those statistics, it is worth considering whether diversity should be a goal for dean search committees.

The legal profession is the least racially diverse profession in the United States, ${ }^{143}$ and the "diversity gap ... has worsened." 144 The ABA and other legal organizations, such as the Institute for Inclusion in the Legal Profession, maintain that diversity strengthens the legal profession and "enhances its ability to serve clients, solve problems, resolve conflicts, and dispense justice." 145 A more diverse profession may be better able to

firms, such as "firms can streamline the process, help deflect those who [are not] great fits with the school, and basically help facilitate the selection," with comments against search firms, such as "I [do not] see the advantage of a search firm for filling out a deanship[, as] [d]eanship vacancies are very public, and anyone interested in being a [d] ean knows how to apply." Id.

141 Lambert, supra note 134.

142 See id. The Illinois legislation included exceptions for recruiting presidents or positions with demonstrated need for a search firm. See Act of July 16, 2012, Pub. L. No. 097-0814, http://www.ilga.gov/legislation/publicacts/fulltext.asp?Name=097-0814\&GA=97.

143 See Deborah L. Rhode, Law Is the Least Diverse Profession in the Nation and Lawyers Aren't Doing Enough to Change That, WAsh. Post (May 27, 2015), https://www.washingtonpost.com/posteverything/wp/2015/05/27/law-is-the-least-diverseprofession-in-the-nation-and-lawyers-arent-doing-enough-to-changethat $/$ utm_term $=.87 \mathrm{~cd} 22 \mathrm{~d} 40056$.

144 Nicole E. Negowetti, Implicit Bias and the Legal Profession's “Diversity Crisis": A Call for Self-Reflection, 15 NEV. L.J. 930, 930 (2015).

145 A Pledge to the Profession, Inst. FOR InCLusion IN THE Legal Prof., 
understand and represent the interests of minority clients. ${ }^{146}$ In addition, there are numerous economic reasons to support diversity. ${ }^{147}$

Yet, as Professor Deborah Rhode recognized, it is ironic that "[i]n principle, the bar is deeply committed to equal opportunity and social justice. In practice, it lags behind other occupations in leveling the playing field."148 Law schools, as the entry point for the profession, are the natural place to begin leveling the playing field. ${ }^{149}$ In fact, the ABA directs law schools to "demonstrate by concrete action a commitment to diversity and inclusion by having a faculty and staff that are diverse with respect to gender, race, and ethnicity." 150 A Diversity in Legal Academia study found that law faculty, as a group, voice support for educational diversity. ${ }^{151}$

Like the broader profession, however, law school faculty, staff, and administrators are not diverse. ${ }^{152}$ This is especially true (and particularly significant) for deans of American law schools. ${ }^{153}$ Lack of diversity among deans matters because the dean "stands alone, and stands above."154 Consequently, "issues of expectation, representation, [and] comfort with and fear of difference operate quite differently when deans are selected, and when they do their jobs." 155 A dean's race, ethnicity, gender, sexual orientation, socioeconomic status, and other characteristics may shape the

http://www.theiilp.com/pledge (last visited June 27, 2018); see also AM. BAR Ass'N, PRESIDENTIAL Diversity Initiative, Diversity in the Legal Profession: THE NEXT STEPS 25 (2010), https://www.americanbar.org/content/dam/aba/ migrated/2011 build/diversity/041511_aba_nextsteps.authcheckdam.pdf ("If any part of our profession ... fails to be diverse and inclusive, we are sending meaningful symbolic messages to members of underrepresented groups, especially those of lower socioeconomic status."); Negowetti, supra note 144 , at $949-50$.

146 See Negowetti, supra note 144, at 951.

147 See Deborah L. Rhode, From Platitudes to Priorities: Diversity and Gender Equity in Law Firms, 24 GeO. J. LegAL ETHICs 1041, 1060-64 (2011).

148 Id. at 1041.

149 See Michael J. Higdon, A Place in the Academy: Law Faculty Hiring and Socioeconomic Bias, 87 ST. JoHN's L. REV. 171, 194 (2013) ("[I]f law schools are truly marketplaces of ideas, then faculty diversity enhances that environment by broadening the number of available perspectives.").

150 Am. BAR Ass'N, StANDARds AND Rules of Procedure, supra note 60, Standard 206(b).

151 See Meera E. Deo, Faculty Insights on Educational Diversity, 83 FordHAM L. REV. 3115, 3138 (2015).

152 See Eboni S. Nelson et al., Assessing the Viability of Race-Neutral Alternatives in Law School Admissions, 102 Iowa L. Rev. 2187, 2201 (2017); see also Statistics Archives: Law School Faculty \& Staff By Ethnicity and Gender, AM. BAR Ass'N, https://www.americanbar.org/groups/legal education/resources/statistics/statistics-archives/ (last visited July 29, 2018) [hereinafter AM. BAR Ass'N, Law School Faculty and Staff].

153 See infra Part III.C.

154 Joan W. Howarth, Recruiting Sexual Minorities and People with Disabilities to be Dean, 31 Seattle U. L. ReV. 751, 751 (2008); see also Johnson, supra note 52, at 814.

155 Howarth, supra note 154 , at 751. 
way “a dean's authority, competence, vulnerability, power, trustworthiness, and strength are interpreted, understood, and experienced." 156 Hiring a diverse candidate as a dean sends a strong message to the law school community, including prospective faculty and students, that the law school celebrates and values diversity. A review of the data shows that most law schools are not yet sending this message.

1. Race

Traditionally, law deans have not been racially diverse. In 1986-1987, there was only one law dean of color at any law school "not populated predominantly by minority students." 157 The numbers have improved since then, but law school deans remain overwhelmingly white. Data from the ABA's 2013 Annual Questionnaire showed that American law deans (not including Associate Deans) were 82.6\% Caucasian, 10.4\% African American, $4.9 \%$ Hispanic, and 2.1\% Asian American. ${ }^{158}$

\section{Gender}

In 2016, the AALS conducted a gender survey of 183 deans in its member law schools. The survey found that $31.1 \%$ of deans were women, while $68.9 \%$ were men. ${ }^{159}$ This is certainly an improvement in gender parity from three decades ago, when only $6 \%$ of American deans were women. ${ }^{160}$ But given the fact that there are now more women than men attending American law schools, ${ }^{161}$ the number of female deans does not match the number of women entering law schools as students.

156 Id. ("Imposed identity issues play out differently when the choice is not just about a colleague, but instead about the person in charge.").

157 Phillips, supra note 7, at 342

158 AM. BAR ASS'N, Law School Faculty and Staff, supra note 152. People of color are slightly more represented in the "Associate" or "Vice Dean" category than in the "Dean Category." See id.; see also Meera E. Deo, Trajectory of a Law Professor, 20 MicH. J. RACE \& L. 442, 443 (2015) (noting that " $83 \%$ of law school deans and $79 \%$ of associate deans are white").

159 See Am. BAR Ass'n, COMM'N On Women In the Profession, A CurRent Glance AT WOMEN IN THE LAW 4 (2017), https://www.americanbar.org/content/dam/aba/marketing/ women/current_glance_statistics_january2017.pdf ("This represents 183 deans at AALS member schools, three of which have two co-deans each, and includes permanent and interim deans.").

160 Phillips, supra note 7, at 342 ("[O]ne current trend is that an increasing number of women have become deans. . . . During the 1986-87 academic year, the number of women deans grew to an all-time high of ten (plus an acting dean), totaling 6\%.").

161 Elizabeth Olson, Women Make Up Majority of U.S. Law Students for First Time, N.Y. TiMES (Dec. 16, 2016), https://www.nytimes.com/2016/12/16/business/dealbook/womenmajority-of-us-law-students-first-time.html; see also Statistics: 2017 JD/Non-JD Enrollment Data, AM. BAR Ass'N, https://www.americanbar.org/groups/legal_education/resources/ statistics/ (last visited Feb. 5, 2019) $(21,523$ women entered U.S. law schools in the fall of 2017 , compared to 19,589 men). 


\section{Sexual Orientation}

A 2011 study revealed that 4\% of American tenured law professors identified as gay, lesbian, or bisexual. ${ }^{162}$ The AALS tracks faculty members who self-identify as members of the LGBTQ population; in 2017, there were 277 faculty members on the list. "Although no real records exist" 163 for deans, openly gay deans in American law schools are "all-too-rare" compared to straight deans. ${ }^{164}$

\section{Socioeconomic Status}

"The term "socioeconomic" is defined... as "of, relating to, or involving a combination of social and economic factors." 165 It would be difficult to determine how many law school deans come from less privileged socioeconomic backgrounds in childhood. But given that most elite law schools overwhelmingly admit economically privileged students, ${ }^{166}$ it is telling that law school deans are predominantly graduates of elite law schools.

Rosenblatt's Dean Database keeps a current list of the law schools that American law deans attended. In 2018, 47 out of 210 law deans (nearly a quarter of them) attended law school at Harvard or Yale. ${ }^{167}$ Nearly half of the deans attended one of nine schools. ${ }^{168}$ This has historically been the case; for example, "[36\%] of those serving as law school deans in 1985-96 received their J.D.' s/LL.B's from five law schools (Harvard, 17\%; Yale, 8\%; Columbia, 5\%; Michigan, 3\%; and Northwestern, 3\%)." law schools traditionally "appear[ed] to be breeding grounds for future deans." $" 170$

162 Elizabeth Mertz et al., Am. Bar Found., After Tenure: Post-Tenure Law PROFESSORS IN THE UNITED STATES 14 (2011), http://www.americanbarfoundation.org/upload $\mathrm{s} / \mathrm{cms} /$ documents/after_tenure_report-_final-_abf_4.1.pdf.

163 Howarth, supra note $1 \overline{5} 4$, at $7 \overline{54}$.

164 Anthony Niedwiecki, A Gay College Dean Takes on Betsy Devos's Transphobia, ADVOC. (Feb. 21, 2018), https://www.advocate.com/commentary/2018/2/21/gay-collegedean-takes-betsy-devoss-transphobia.

165 Michele Benedetto Neitz, Socioeconomic Bias in the Judiciary, 61 CLEV. ST. L. REV. 137, 145 (2013) [hereinafter Benedetto Neitz, Socioeconomic Bias] (citing Socioeconomic, WEBSTER's NEW INT'L DictionARY (3d ed. 1986)).

166 See Higdon, supra note 149, at 175.

167 Law Schools Deans Attended, Miss. C. Sch. Of L.: RosenblatT's Dean Database, http://www.law.mc.edu/ deans/results.php?s=6 (last visited June 11, 2018).

168 More specifically, 103 of 210 current law deans attended one of the following nine schools: Harvard (27 deans); Yale (22); Columbia (12); University of Michigan (11); Stanford (8); Georgetown (7); University of Chicago (5); University of Virginia (6); and New York University (5). Id.

169 Phillips, supra note 7, at 332.

170 Id. at 334 (referring to "Harvard, New York University, Virginia, Yale, Boston University, University of California at Los Angeles, Chicago, Illinois, Michigan, Minnesota, 
Accordingly, most law school deans began their careers as graduates of elite institutions, and therefore as members of a privileged class. Even deans who may have experienced lower socioeconomic status before attending law school received the career advantages resulting from attendance at an elite institution. As discussed, this raises concerns that law school deans may begin their positions of leadership without familiarity with diverse socioeconomic viewpoints. ${ }^{171}$

It is worth noting that more research is needed to properly assess the intersection of these diverse categories, such as deans who identify as both people of color and members of the LGBTQ community. In addition, although the diversity of American deans has certainly improved in the last decade (or two), the available statistics demonstrate the need for increased diversity as part of the dean search process. Moreover, diversity in dean searches has become a contentious point on campuses nationwide. ${ }^{172}$

It is clear that the dean search process is an increasingly visible representation of a law school's commitment to diversity (or lack thereof). It is therefore critical that dean search committee members approach their tasks without the influence of bias.

\section{Bias IN THE DEAN SEARCH PROCESS}

\section{A. Explicit vs. Implicit Bias}

Explicit bias is fairly easy to recognize. It is "deliberately generated and consciously experienced as one's own" belief. ${ }^{173}$ For example, if a dean search committee expressly stated in its first meeting, "we will not be interviewing any women or any individuals from non-elite schools for our dean position," the committee would be expressing explicit gender and socioeconomic bias. ${ }^{174}$ Acting on certain explicit biases, such as racial or

and Pennsylvania").

171 See infra Part IV.G.

172 See Michelle Jacobs, Failed Dean Search Delivers a Terrible Blow to Law School, GAINESVILLE.COM (Mar. 27, 2014), http:/www.gainesville.com/article/LK/20140327/News/ $604134327 / \mathrm{GS} /$. For a discussion of a failed dean search, see infra Part IV.C.

173 J. Bernice B. Donald \& Sarah E. Redfield, Framing the Discussion, in ENHANCING JUSTICE: REDUCING Bias 5, 14 (Sarah E. Redfield ed., 2017).

174 Explicit bias examples do exist in the context of a dean search. For example, Texas Tech University School of Law Associate Dean Daisy H. Floyd sued the University when she learned the president had told the outgoing dean "in the lewdest and crudest of terms" that he would not hire a woman to be a law school dean. Betsy Blaney, Law School Professor Sues Tech, Alleges Discrimination, MYPLAINVIEw (May 1, 2003), https:/www.myplainview.com/ news/article/Law-school-professor-sues-Tech-alleges-8828125.php. According to the complaint, Associate Dean Floyd was told she "could forget about being interim dean" because of sexism. Id. The suit was ultimately withdrawn when Associate Dean Floyd became the Dean of Mercer University School of Law. Michael Castellon, Floyd Drops Latest Lawsuit Against the Law School, UnIV. DAILY (Jan. 21, 2004), https://ttu-ir.tdl.org/ttu- 
gender bias, results in discrimination that is prohibited by the U.S. Constitution. ${ }^{175}$ Agencies regulating law schools, including the ABA, also expressly prohibit acting in a discriminatory manner against students, faculty, or staff on the basis of "[r]ace, color, religion, national origin, gender, sexual orientation, age, or disability." 176 Although some explicit bias may exist in dean hiring, such as socioeconomic bias on the basis of a candidate's educational background, ${ }^{177}$ most discriminatory manifestations of explicit bias would not be permitted (and are in fact specifically prohibited) in most law schools. Consequently, this Article will focus on the more difficult issue of implicit bias.

Implicit bias differs from explicit bias because it is not as easily identifiable, even by the person holding the biased beliefs. In fact, all of us have some form of implicit bias, which can be defined as "an association or preference that is not consciously generated and is experienced without awareness. ${ }^{178}$ Because these associations are unconscious, and are "activated involuntarily," they can "affect our understanding, actions and decisions" even when we do not realize it. ${ }^{179}$ Furthermore, implicit biases may be different from "what we actively and honestly believe."180

Everyone holds implicit biases, which are based on beliefs that could stem from childhood experiences, opinions of friends or family members, or from media and news outlets. ${ }^{181}$ Media is especially influential in American society. ${ }^{182}$ The rise of the "echo chamber" of social media, combined with

ir/bitstream/handle/10601/1420/Floyd\%20drops\%20suit\%20UD01212004.pdf?sequence=1.

175 See U.S. CONST. amends. V, XIV; see also 42 U.S.C. § 2000e-2 (2018).

176 Am. BAR Ass'N, StANDARds AND Rules of Procedure, supra note 60, Standard 205(b) ("A law school shall foster and maintain equality of opportunity for students, faculty, and staff, without discrimination or segregation on the basis of race, color, religion, national origin, gender, sexual orientation, age, or disability."); see also AALS Handbook: Bylaws, supra note $64, \S 6-3$.

A member school shall provide equality of opportunity in legal education for all persons, including faculty and employees with respect to hiring, continuation, promotion and tenure, applicants for admission, enrolled students, and graduates, without discrimination or segregation on the ground of race, color, religion, national origin, sex, gender (including identity and expression), sexual orientation, age, or disability.

Id.

177 See infra Part IV.G.

178 See Donald \& Redfield, supra note 173, at 14.

179 Understanding Implicit Bias, OHIO ST. U. KIRWAN INST., http://kirwaninstitute.osu.edu/research/understanding-implicit-bias/ (last visited Feb. 5, 2019) [hereinafter KIRWAN INST.].

180 Donald \& Redfield, supra note 173, at 14; see also John F. Irwin \& Daniel L. Real, Unconscious Influences on Judicial Decision-Making: The Illusion of Objectivity, 42 McGeorge L. ReV. 1, 3 (2010).

181 See KIRWAN INST., supra note 179.

182 Michele Benedetto Neitz, When Myths Become Beliefs: Implicit Socioeconomic Bias 
the consolidation of corporate ownership of many mainstream media outlets, means that most Americans consume news from sources with a strong slant toward a particular viewpoint. ${ }^{183}$ This leads to a "confirmation bias" resulting from only learning information from sources that already support our viewpoint. ${ }^{184}$ In this way, even untrue news stories may be relied upon to shape our personal narratives about cultures and people who are different from our own.

These narratives and beliefs give rise to implicit biases because they can "cause us to have feelings and attitudes about other people based on characteristics such as race, ethnicity, age, and appearance." 185 The result could be biased decision-making processes, even if we are not consciously aware that our cognitive analyses are influenced by bias. ${ }^{186}$ This would obviously have significant ramifications in a hiring situation, such as a dean search. But unlike explicit bias, implicit bias is much more difficult to track or measure.

\section{B. How Do We Know Implicit Bias Exists?}

One method used to analyze implicit biases is the Implicit Association Test (IAT), a "computerized priming test that measures [implicit] associations using pictures and words." ${ }^{187}$ The test asks participants to pair an attitude object, such as a racial group or gender group, with an evaluative dimension, such as "good" or "bad."188 Participants press a response key quickly, without time to think through their reactions. ${ }^{189}$ Accordingly, the participant's "response speed indicates implicit and automatic attitudes and stereotypes." 190 The IAT can have surprising results, since people with strong implicit biases may not claim to hold such biases. ${ }^{191}$

The IAT has its critics; it can be difficult "to know whether the IAT is measuring something entirely unconscious or partially unconscious." 192 Some question whether the IAT is useful if it cannot predict real-world

\footnotetext{
in American Courtrooms, in ENHANCING JusticE: ReducING BiAs 131, 133 (Sarah E. Redfield ed., 2017) [hereinafter Benedetto Neitz, When Myths Become Beliefs].

183 Id.

184 Id

185 See KIRWAN INST., supra note 179.

186 See Daniel Kahneman, Thinking, FAST And Slow 24 (2011).

187 Donald \& Redfield, supra note 173, at 14.

188 Justin D. Levinson et al., Implicit Bias: A Social Science Overview, in ENHANCING JusticE: REdUCing BiAs 43, 51 (Sarah E. Redfield ed., 2017) [hereinafter Levinson et al., Implicit Bias].

189 Id.

190 Id.

191 Id

192 Id. at 52.
} 
behaviors. ${ }^{193}$ Others argue that implicit bias discourse itself may lead to more explicitly biased behavior. ${ }^{194}$ Nevertheless, at this point, the IAT remains a useful technique for understanding and recognizing implicit bias. Even without the IAT, "[t]here is a mountain of evidence-independent of any single test - that implicit bias is real." 195

This is especially important in the context of a law school dean search, because multiple studies show a "meaningful connection between implicit bias and various types of discrimination." 196 Dean search committee members, most of whom are highly educated with strong cognitive abilities, would likely bristle at the very thought that they hold implicit associations based on race, gender, sexual orientation, or socioeconomic status. ${ }^{197}$ While committee members may indeed hold implicit biases against candidates from a particular group, dean search committee members are also likely to manifest a specific type of implicit bias in favor of candidates. This bias is known as "in-group favoritism."

\section{In-group Favoritism}

In-group favoritism is a "term used to associate one's in-group with pleasantness more than an out-group." 198 Our "in-group" is defined as those who share particular characteristics with us, such as race, gender, socioeconomic or educational status, and sexual orientation. ${ }^{199}$ No matter how we define those characteristics, we generally tend to hold implicit biases

193 Id.; see also Keith Payne et al., How to Think About “Implicit Bias”, SCI. AM. (Mar.

27, 2018), https://www.scientificamerican.com/article/how-to-think-about-implicit-bias/ ("[T]he [IAT] does have limitations. The stability of the test is low, meaning that if you take the same test a few weeks apart, you might score very differently. And the correlation between a person's IAT scores and discriminatory behavior is often small.").

194 See, e.g., Michael Selmi, The Paradox of Implicit Bias and a Plea for a New Narrative, 50 ARIZ. ST. L.J. 193, 197 (2018) (“[A]lthough the implicit bias literature is designed to make the legal system more receptive to bias, it has likely had the opposite effect. Defining contemporary discrimination as unconscious and beyond one's control is not just inaccurate descriptively, but it makes such bias more difficult to prove.").

195 Payne et al., supra note 193; see also Levinson et al., Judging Implicit Bias, supra note 2, at 81 (describing other methods employed by social scientists "to test how implicit biases affect cognitive processing and behavior across a wide range of groups").

196 Levinson et al., Implicit Bias, supra note 188, at 53.

197 See Matthew D. Lieberman et al., Breaking Bias, NeUroLeAdershiP J., May 2014, at 4 ("People do not want to believe that they are biased. . . . In fact, even high cognitive ability does not protect someone from the effects of bias.").

198 Peter Koelling, Professor Greenwald Interview, in ENHANCING Justice: Reducing Bias 187, 189 (Sarah E. Redfield ed., 2017).

199 See Sarah Q. Simmons, Litigators Beware: Implicit Bias, 59 Advoc. 35, 35 (2016) ("[R] esearch in neurology and social and cognitive psychology reveals that we are all subject to unconscious biases that tend to favor those socially similar (e.g., race, ethnicity, gender, socioeconomic status) to ourselves."); see also Donald \& Redfield, supra note 173, at 18. 
that favor our own in-group. ${ }^{200}$ For example, law professors may view other law professors as more "competent," "intelligent," or more "concerned with their groups' goals" than those who are not law professors. ${ }^{201}$

In-group favoritism is especially problematic in hiring decisions. "Many ... types of connections between people - including ones due to shared race, ethnicity, age, [or] religion" - can tip the balance toward giving a member of one's in-group "the benefit of the doubt." 202 In dean searches, as in other hiring situations, existing employees are asked to help find candidates for job openings. ${ }^{203}$ This could lead, for example, to white dean search committee members "drawing on virtually all-White acquaintanceship networks, to seek out only other whites for job vacancies." 204 Even without any malice or hostility toward people outside the committee member's in-group, this "unremarkable process can sustain or exacerbate racial or other imbalances." 205 In a nutshell, in-group favoritism may lead dean search committee members to prefer candidates who look like them or share their educational backgrounds, even if those committee members do not hold implicit or explicit biases against outgroups.

The subtle nature of in-group favoritism may explain why some researchers believe that, "at least in the United States, ingroup favoritism is the prime mechanism of discrimination." "206 It is also very likely to be the main form of bias manifested on the part of dean search committees; in the rarified setting of law school dialogues, it is deemed more acceptable to vocalize opinions based on positive "biases" in favor of a dean candidate from one's in-group, rather than vocalizing negative biases against particular out-groups. In-group favoritism and other forms of implicit bias, however, "often have very real impacts on the decisions one makes." 207

These impacts can be quite noticeable in law dean searches. Any university search committee would say that they "of course, absolutely hope to avoid [any] bias."208 But in reality, "committee after committee avows

200 See Donald \& Redfield, supra note 173, at 18; see also KIRWAN InST., supra note 179.

201 Donald \& Redfield, supra note 173, at 18; see also Deborah L. Rhode, The Subtle Side of Sexism, 16 COLUM. J. GENDER \& L. 613, 619 (2007) [hereinafter Rhode, The Subtitle of Sexism] (In-group favoritism may manifest in a "presumption of competence that dominant groups accord only to insiders").

202 Anthony D. Greenwald \& Thomas F. Pettigrew, With Malice Toward None and Charity for Some: Ingroup Favoritism Enables Discrimination, 69 AM. PsYCHOL. 669, 669 (2014).

203 See id.

204 Id. (citation omitted).

205 Id.

206 Id. at 670

207 Irwin \& Real, supra note 180, at 4.

208 MARCHESE \& LAWRENCE, supra note 73, at 54. 
commitment to [diversity], trumpets it in ads, finds a relevant candidate or two to keep alive for a while, [and] then nominates a slate of white males."209 When challenged about the search result, the committee's usual response is, "[w]e [could not] find a woman or Hispanic we liked." 210

An illustrative example of this phenomenon may be found in the University of Florida Levin College of Law's recent "failed" dean search. ${ }^{211}$ The dean finalists had included an African-American dean from a different law school and an openly gay former U.S. Ambassador. When the president and provost declared that they "did not find one (candidate) ideally suited to lead the College" 212 faculty, staff, and students experienced "anger and embarrassment." ${ }^{213}$ Concerned faculty member Michelle Jacobs wrote in a Gainesville newspaper that the president's "decision deliver[ed] a terrible blow to" faculty and students, "damag[ing] our institution in the eyes of our peers throughout the country.",14

This problem may be attributed in part to a "failure to search actively for talented women and minorities." ${ }^{215}$ But the problem is also the result of in-group favoritism, in which candidate pools are "stripped dry at successive stages" without "apparent bias of race or sex," but with minority candidates rejected nonetheless. ${ }^{216}$ In order to fully explain this occurrence, the next section will examine the manifestation of implicit bias and in-group favoritism in dean searches on the basis of race, gender, sexual orientation, and socioeconomic status.

\section{Implicit Racial Bias}

As noted above, law schools are prohibited (by the ABA and the Constitution) from making discriminatory hiring decisions based on race. ${ }^{217}$ Yet, a review of hundreds of thousands of IAT results found that " $68[\%]$ of participants demonstrated an implicit preference for 'white people' versus "black people." "218 Implicit racial bias is well documented in social science Racial Bias ACross the LAw 9, 17 (Justin D. Levinson \& Robert J. Smith eds., 2012) [hereinafter Levinson et al., Implicit Racial Bias]; see also Giovanna Shay, In the Box: Voir Dire on LGBT Issues in Changing Times, 37 HARV. J.L. \& GENDER 407, 425 (2014) (Studies analyzing IAT results have found that "the vast majority of white Americans demonstrate implicit bias against African Americans").
} 
research, and can be based on a person's race, skin tone (known as "colorism"), or even facial features. ${ }^{219}$

Could implicit bias be responsible for the low numbers of deans of color in American law schools? In the context of law faculty members, "racial and gender disparities ... cannot be blamed on a lack of either applicants or qualified potential candidates, as the pool of possible law professors contains significantly higher percentages of both women and people of color than are in law teaching today." 220 The same is likely true for dean candidates.

Professor Meera Deo's "Diversity in Legal Academia (DLA) project" is "the first formal empirical study of . . . law faculty" diversity. ${ }^{221}$ One participant in Professor Deo's study reported that her faculty had interviewed a Muslim woman wearing a hijab for a faculty position. A white colleague on the faculty stated his objection to hiring the Muslim candidate, based not on any criticism of her teaching or writing ability, but "on his general sense of discomfort being around her." ${ }^{222}$ The candidate was not hired. Professor Deo makes the point that the white faculty member may not have been consciously aware of any racial or ethnic (or religious) bias against the Muslim candidate, but he may have been uncomfortable "simply because [his] subconscious reacts negatively to the image and association of a woman in hijab."223

The Muslim woman applying for a law teaching position may have had the same experience if she were applying for a dean position. ${ }^{224}$ Allegations of bias in dean selections have surfaced in law schools in the last few years. For example, when the dean of the George Washington University Law School stepped down in 2012, the University selected Professor Gregory Maggs, a popular professor who had previously served as an interim dean, to take on the role again. ${ }^{225}$ One faculty member, however, wrote in an email to the faculty that she believed the university leaders "overlooked" the law school's senior associate dean for academic affairs, Christopher Bracey, because he is African-American: "I must express my own view that any faculty opposition to Sr. Associate Dean Bracey moving into the interim deanship was racially based[.."226 Other law professors objected to the

219 See Levinson et al., Implicit Racial Bias, supra note 218, at 9; see also Bennett \& Plaut, supra note 3 , at 752 .

220 Deo, supra note 158 , at 458.

221 Id. at 445.

222 Id. at 462

223 Id. at 463

224 As described in the dean selection process, supra Part III.B, faculty members usually vote for or against a candidate before university administrators have their say.

225 Cory Weinberg, Law School Picks Two-Time Interim Dean, GW HATCHET (Dec. 3, 2012), https://www.gwhatchet.com/2012/12/03/law-school-picks-two-time-interim-dean/.

226 Id. 
charges in the e-mail, arguing that the interim dean was selected based on his previous experience. The interim dean decision ultimately was not changed. ${ }^{227}$

The selection of an interim dean is made by university leadership, and is different than the usual dean selection process. Dean search committee members, however, should be aware that multiple studies have demonstrated the prevalence of implicit racial bias in hiring decisions in other contexts. For instance, for a 2003 "field experiment" published in the National Bureau of Economic Research, researchers sent resumes with names that sounded either African-American or White. ${ }^{228}$ The White names received $50 \%$ more callbacks than the African-American names, leading the researchers to conclude that racial discrimination "appears to still be prominent in the U.S. labor market." 229 In light of the statistics demonstrating racial disparity in the selection of deans, and studies proving the existence of implicit bias and racial discrimination in the broader labor market, it is not a leap of logic to suggest that implicit racial bias influences dean searches in American law schools.

\section{E. Implicit Gender Bias}

In a 1973 article detailing a successful dean search, the dean search committee chairs explained the importance of women in their positions as wives to law dean candidates:

Selling the wife is extremely important, particularly if the school is geographically removed from friends, family, and past experience. We suggested faculty wives to help host the visits, but most candidates' wives preferred informal get-togethers. In some instances lack of interest in the position was attributed to the wife's unwillingness to move to the West Coast. ${ }^{230}$

This quotation, considered in its historical context, identifies the role of women in dean searches forty years ago: as either the wives of the candidates, or as "faculty wives" of existing law professors. ${ }^{231}$ There is no

227 Id. Senior Associate Dean Christopher Bracey is now the Vice Provost for Faculty Affairs at George Washington University Law School. Christopher A. Bracey, GW LAw, https://www.law.gwu.edu/christopher-bracey (last visited Oct. 27, 2018). Professor Gregory Maggs is now a judge of the United States Court of Appeals for the Armed Forces. See Senate Confirms Professor Gregory Maggs as Judge to U.S. Court of Appeals, GW LAW, https://www.law.gwu.edu/senate-confirms-professor-gregory-maggs-judge-us-court-appeals (last visited Oct. 27, 2018).

228 See Nancy Gertner \& Melissa Hart, Employment Law: Implicit Bias in Employment Litigation, in IMPLICIT RACIAL BIAS ACROSS THE LAW 80, 83 (Justin D. Levinson \& Robert J. Smith eds., 2012); see also Bertrand \& Mullainathan, supra note 93, at 992.

229 Bertrand \& Mullainathan, supra note 93, at 991.

230 Lazerow \& Winters, supra note 80 , at 74 n.8.

231 Id. 
mention in this article of female dean candidates or female faculty members voting for the candidates. Historically,

[A]lmost no women were considered for academic leadership positions and almost no women were on the committees or boards of trustees that passed judgment on candidates. A representative example involves the Yale presidential search process in the late 1980 s, when the entire short list was all white men, and the explanation was that no one else had the required "gravitas." When asked what had been done to ensure an inclusive search, the secretary to the committee responded without irony that an advertisement for the position of president had been placed in the Chronicle of Higher Education, which included the assurance that Yale was an equal opportunity employer. ${ }^{232}$

Today, of course, women are much more likely to be dean search chairs or dean candidates. Even so, the statistics discussed above demonstrate that women are not hired as deans as often as men, suggesting that implicit gender bias may still be an issue in dean searches. For example, committee members and other faculty members may implicitly believe that "women may not be tough enough, rigorous enough, or sufficiently inspiring to be successful either at fund-raising or institutional leadership." 233 Moreover, dean "[s]earch committees may discount the ability of women with small children to handle such a time-consuming and stressful position." 234 During a recent dean search at a Southern law school, it was brought to the attention of the search chair that there were no women finalists in the dean pool. The chair's response ("But we just had a woman dean!") suggested that women deans should be hired only in small numbers. ${ }^{235}$

Concerns about women as leaders are certainly not limited to the law dean context. Implicit stereotypes about the roles of women and men in the home and workplace contribute to these beliefs. As Professor Rhode explains, colleagues may assume that a working mother who leaves the office early is doing so for family reasons, while a working father's departure from work may not "trigger the same assumption[s]."236 This can occur "even if individuals' conscious beliefs are relatively free of prejudices." 237

232 E-mail from Deborah Rhode, supra note 113.

233 Herma Hill Kay, Women Law School Deans: A Different Breed, or Just One of the Boys?, 14 YALE J.L. \& Feminism 219, 233 (2002).

234 Id.

235 Interview with Anonymous Dean 2 (July 23, 2018).

236 Rhode, The Subtitle of Sexism, supra note 201, at 618; see also Justin D. Levinson \& Danielle Young, Implicit Gender Bias in the Legal Profession: An Empirical Study, 18 DUKE J. GENDER L. \& POL'Y 1, 10-11 (2010).

237 Rhode, The Subtitle of Sexism, supra note 201, at 618. 
In fact, many "popular assumptions" about women's willingness to be leaders and doubts about their abilities to perform these roles well are "based on very thin evidence." 238 In law schools, women may actually be doing much of the work of a dean already. A female participant in Professor Deo's DLA project recounted that during a dean search, "it occurred to me and [another woman of color on my faculty] to say, 'We already do a lot of this work, but we [are not] getting any of the recognition." 239 In fact, women faculty members may be "overlooked for the formal leadership positions, though they tend to do much of the work already." 240

The historical absence of women and people of color also creates a vacuum for mentorship. For women faculty who aspire to be deans, especially women of color, there are fewer role models who can mirror the experience of moving into a dean role. ${ }^{241}$ This could change as more women become law school deans, but " unless there are dramatic changes in the way law school deans are hired,' the female percentage of deans may not equal the female percentage of professors 'at any time in the foreseeable future.", 242

\section{F. Implicit Sexual Orientation Bias}

Unlike race and gender, sexual orientation is not a protected class under the Constitution. ${ }^{243}$ Even so, the ABA Standards forbid law schools from discriminating on the basis of sexual orientation. ${ }^{244}$ This was not always true, as explicit sexual orientation discrimination was not uncommon in law schools in previous decades. For example, at a 1992 program encouraging minority attorneys to consider law teaching, panelists repeatedly stated comments along the lines of, "[a]lthough I cannot say that this is yet true for gays and lesbians, it really is true that law schools want people of color and women for their faculties." 245 One of the first openly gay deans in an American law school, Craig Christiansen, recounted a story in which he was called into the office of a senior officer at his university. The officer

\footnotetext{
238 Hill Kay, supra note 233, at 234; see also Deborah L. Rhode, The Difference "Difference” Makes, in The DifFERENCE "DifFERENCE" MAKES: WOMEN AND LEADERSHIP 3, 19-20 (Deborah L. Rhode ed., 2003).

239 Deo, supra note 158, at 472.

240 Id.

241 See id. at 469.

242 Hill Kay, supra note 233, at 238 (quoting Richard K. Neumann Jr., Women in Legal Education: What the Statistics Show, 50 J. LEG. EduC. 313, 324 (2000) (emphasis in original)).

243 See U.S. CONST. amends. V, IX.

244 See Am. BAR Ass'N, StAndARds And Rules of Procedure, supra note 60, Standard 205(b).

245 Howarth, supra note 154, at 755.
} 
explained, "[s]urely you must understand that ultimately you will have to make a choice. You cannot possibly be both dean of a law school and openly gay." 246

In recent years, many individuals are less willing to admit open prejudice against members of the LGBTQ community, and this form of explicit bias is unlikely to be apparent in most law schools. The "gay rights movement has slowly succeeded in ending some conspicuous forms of . . . discrimination against gay people as a group." 247 One openly gay dean noted that although he anticipated questions such as "what does your wife do?" during his dean interview, he was pleased that his sexual orientation was never mentioned during the interview process. ${ }^{248}$ While this means outright bias is less prevalent, it also means "discrimination against gay people on the basis of their sexual orientation will ... shift and take new forms." 249 One of these forms is implicit sexual orientation bias.

Recent IAT results revealed that "[n]early $83 \%$ of heterosexuals ... manifested implicit bias in favor of straight people over gays and lesbians." ${ }^{250}$ Even "many egalitarian-minded heterosexual individuals [who] sincerely believe gays and lesbians should not be discriminated against and self-report positive attitudes about homosexuality [will] manifest implicit bias in favor of heterosexuality and against homosexuality." 251 During this era of rapidly changing explicit attitudes in favor of same-sex sexuality, "we are not yet at a point where we can concentrate entirely on eradicating this implicit bias." 252

Scientists ascribe negative implicit sexual orientation bias to traditional gender roles and concepts of sexual identity. ${ }^{253}$ A specific example is "the pervasive stereotype that gay men possess feminine characteristics." 254 This stereotype is especially strong for straight men who "strongly adhere to

246 Id. at 753-54 (citing Craig W. Christensen, President, Law Sch. Admissions Servs., Address at the 1990 Annual Meeting Plenary Session of the Association of American Law Schools: The Trivial Concerns of the Invisible Minority (Jan. 6, 1990)).

247 Luke A. Boso, Acting Gay, Acting Straight: Sexual Orientation Stereotyping, 83 TENN. L. REV. 575, 620 (2016).

248 Telephone Interview with Anonymous Dean 1 (July 9, 2018).

249 Boso, supra note 247, at 620.

250 Cynthia Lee, The Gay Panic Defense, 42 U.C. DAVIS L. Rev. 471, 539 (2008); see also A. Nicole Kwapisz, Classification of Homosexuals Under the Equal Protection Clause: Forward-Looking Disparate Impact Test, 5 DePAuL J. Soc. Just. 71, 107-08 (2011).

251 Lee, supra note 250, at 547. But see Amanda B. Breen et al., Implicit and Explicit Attitudes Toward Gay Males and Lesbians Among Heterosexual Males and Females, $153 \mathrm{~J}$. Soc. Psychol. 351, 374 (2013) (finding either positive or neutral attitudes toward gay people).

252 Shay, supra note 218 , at 425.

253 See Kwapisz, supra note 250, at 108-09.

254 Id. at 109. 
cultural standards of masculinity."255 For these men, negative prejudice toward homosexual men "represents straight men's endorsement of their own 'masculine gender role for men." "256 The stronger the implicit attitude or stereotype, "the more profound the behavioral response exhibited in uncomfortable body language." 257

An openly gay faculty member applying for a dean position recently encountered this phenomenon. ${ }^{258}$ In response to a question about the candidate's commitment to diversity, the candidate explained that being gay meant he was more sensitive to the issues facing all diverse groups. He immediately noticed two men on the committee become visibly uncomfortable when he mentioned he was gay, signaling that they harbored implicit sexual orientation bias even if they were not consciously aware of it. ${ }^{259}$ The candidate was not hired for the deanship. ${ }^{260}$

At this point, there is no hard evidence proving why there are so few openly gay deans in American law schools. This theory about sexual orientation bias and stereotypes, however, appears anecdotally to be prevalent in the law school setting. For example, Dean Anthony Neidwiecki explains:

I always tended to relate more to strong women and those were the leaders I looked at. A lot of gay men do that because in some ways, the down-the-line discrimination is based on very similar things: the perception of being weak or being unable to do things. I theorize that the reason why there are so few deans that are openly gay is because of that underlying stereotyping. ${ }^{261}$

Indeed, while "openly gay candidates may pass unremarkably through scrutiny for faculty roles by a committee focused on academic accomplishment and teaching skills," they may be less likely to be hired for leadership positions "where committees of mixed constituencies bring to the table biases about how [deans] and their trailing family members ought to appear." 262

255 Id. (alterations in original omitted) (quoting William A. Jellison et al., Implicit and Explicit Measures of Sexual Orientation Attitudes: In Group Preferences and Related Behaviors and Beliefs Among Gay and Straight Men, 30 PersonAlity \& Soc. Psychol. BULl. 629, 631 (2004)).

256 Id.

257 Id. at 109-10.

258 Interview with Anonymous Dean 1 (July 9, 2018).

259 Id

260 Id

261 Kevin Truong, Golden Gate University Law School Dean Fights Homophobia and Fear, S.F. Bus. TiMES (June 14, 2018), https://www.bizjournals.com/sanfrancisco/news/2018 /06/14/ggu-law-school-dean-fights-homophobia-fear.html.

262 Lucy A. Leske, How Search Committees Can See Bias in Themselves, CHrON. HigHER EDU. (Nov. 30, 2016), https://www.chronicle.com/article/How-Search-Committees-Can- 
Dean search committee members should consider how sexual orientation stereotypes might manifest during a search process on their campuses, in some cases with an effect on the outcome of the search. ${ }^{263}$ The solution to the problem of implicit sexual orientation bias "is not to pretend that we live in a post-Will and Grace world in which we have conquered homophobia, but rather to identify appeals to bias and confront them directly." 264

\section{G. Implicit Socioeconomic Bias}

Implicit socioeconomic bias is not a mainstream topic. ${ }^{265}$ Part of the reason for the lack of attention on implicit socioeconomic bias is the subtle nature of this type of bias. Just as it is unlikely that a judge would announce that he or she is "biased against poor people,"266 it is similarly unlikely that a dean search committee member would declare that he or she "do[es] not want to hire a dean who comes from a disadvantaged economic background."

It is likely, however, if not probable, that a dean search committee member or a university administrator would say that he or she "wants to hire a dean with a high profile who graduated from an elite school." In fact, many job announcements in the legal profession specifically state that the job requires a "J.D. or equivalent from an excellent law school," or include language such as, "[t]he candidate must have superior academic credentials including graduation from a top law school." 267

If "excellent" or "top" law schools were representative of the diverse socioeconomic classes in the United States, this type of job requirement would not imply the existence of socioeconomic bias. In actuality, "the students who attend top-tier law schools are overwhelmingly representative of the elite socioeconomic class - often times as a result of merely being born to parents who were also a member of that class." ${ }^{268}$ As economic inequality in the United States increases, law school is becoming increasingly unattainable for people in lower economic classes. In fact, one study found that only 5\% of American law students come from families in

See/238532? cid $=$ cp83.

263 See Kwapisz, supra note 250, at 110 ("Although these behavioral manifestations may initially seem insignificant, they often carry social, ethical and legal implications because the parties involved in such nonverbal behavior are not even aware that they engage in discrimination.").

264 Shay, supra note 218 , at 444.

265 In fact, this author is the only one to date who has published in detail in legal academic literature about the topic. See generally Benedetto Neitz, When Myths Become Beliefs, supra note 182, at 132-33; see also Benedetto Neitz, Socioeconomic Bias, supra note 165, at 137.

266 Benedetto Neitz, Socioeconomic Bias, supra note 165, at 147.

267 The phrases in this paragraph come from actual job postings on Indeed.com for attorney positions in the San Francisco Bay Area on June 26, 2018.

268 See Higdon, supra note 149, at 175. 
the bottom half of the national socioeconomic distribution. ${ }^{269}$ This lack of socioeconomic diversity has real implications for the legal education experience and the larger legal profession. ${ }^{270}$

Law faculties and administrative positions, including dean positions, are even less socioeconomically diverse than most student bodies. Indeed, "over $40 \%$ of current law professors attended either Harvard or Yale for law school and the vast majority (over $85 \%$ ) of current law professors attended one of twelve elite law schools, regardless of where they themselves currently teach." ${ }^{271}$ Most law professors are deemed qualified for teaching jobs because they performed well in a "top" law school. ${ }^{272}$

The same is true for deans. The statistics referenced earlier in the Article $^{273}$ show that successful dean candidates overwhelmingly attended elite schools. Dean search committees are likely to equate graduation from an elite school with strong intellectual ability, and exceptional leadership and administrative skills. ${ }^{274}$ This assumption underlies many steps of the dean search process, but it is especially relevant in the resume review stage. At this early point, "[we are] all eager to spot the 'rising star,' the 'real comer'Ivy grad . . . [elite law school diploma] . . . two books, a professorship, ready at 36 for your deanship." 275

Unfortunately, this form of implicit bias may actually hurt the chances of a successful dean search, since "the real talent ... want[ed] for [a dean] position probably will not be 'to the manor born.",276 Non-privileged or minority candidates may have experienced discrimination as they moved through the educational system. ${ }^{277}$ Dean search committees who look beyond elite diplomas and prestigious work experiences may find outstanding leadership abilities in nontraditional dean candidates. In fact:

\footnotetext{
269 See id. at 182 (citing Richard H. Sander, Class in American Legal Education, 88 DENV. U. L. REV. 631, 632 (2011)).

270 See id. at 194 ("Is it not at least arguable that [professors from lower socioeconomic backgrounds] would bring a different perspective to the classroom - one that some of the students in the classroom can relate to first-hand and one to which the other students likely need some exposure?").

271 Deo, supra note 158 , at 460.

272 Peter Keane, Interloper in the Fields of Academe, 35 U. ToL. L. REV. 119, 123 (2003) ("As a result, the world of law school faculty [may be viewed as] a cul-de-sac of inbreeding, intellectual incest, and an almost total lack of real world imagination or creativity.").

273 See supra Part III.C.

274 See Leske, supra note 262 (noting that many search committees begin evaluations of candidates with their "educational pedigree" thereby "making immediate and implicit assumptions about background, intelligence, and intellectual capacity").

275 MARCHESE \& LAWRENCE, supra note 73, at 54.

276 Id.

277 See Leske, supra note 262.
} 
There are many good reasons why able people started out in colleges you never heard of, majored in nursing or sociology or teacher ed, display deviant "gaps" in their resumes (for community work, family, the army), took 13 years for a doctorate [or J.D.] at a regional university, and are now working at a community college. Unless [you are] willing to look closely at what candidate[s] have actually achieved and can do in your position, screening by "prestige" factors becomes a talent loser. ${ }^{278}$

Dean search committees who are aware of implicit socioeconomic bias in the legal profession will take the time to locate candidates without elite backgrounds, and will expand interview questions and discussions to include time for a candidate to explain a nontraditional career path. ${ }^{279}$ Moreover, there are additional affirmative steps committees can take to minimize implicit bias during a dean search.

\section{RECOMMENDATIONS: How to REMEDy Bias In THE DEAN SEARCH PROCESS}

This part will review three proposals for dean search committees to minimize implicit bias during a search: (1) de-biasing techniques for individual committee members; (2) de-biasing techniques for the law school institution; and (3) radically re-thinking the traditional dean search process.

\section{A. De-biasing Techniques for Individuals}

An individual's implicit biases can be changed. Our brains are malleable, and "the implicit associations that we have formed can be gradually unlearned through a variety of de-biasing techniques." ${ }^{280}$ These techniques usually begin with increasing awareness of the way implicit bias affects our cognitive processes, including the decision-making processes required in a dean search. ${ }^{281}$ Simply being aware of how implicit bias works, however, is not enough to combat it. ${ }^{282}$

Mindfulness: Many implicit bias experts would next suggest reflective thinking and mindfulness as a way to slow down our thought processes and challenge any bias that arises. ${ }^{283}$ Pausing before making decisions and

278 MARCHESE \& LAWRENCE, supra note 73, at 54 (emphasis in original).

279 See Weiss, supra note 14, at 930 (discussing how committees should not use academic experience or tenure as a major factor in dean selection).

280 KIRWAN INST., supra note 179.

281 Cynthia Lee, Awareness as a First Step Toward Overcoming Implicit Bias, in EnHANCING Justice: Reducing Bias 289, 291 (Sarah E. Redfield ed., 2017).

282 See id. at 295 (" $[\mathrm{I}] \mathrm{t}$ appears that simply telling people that they should try to avoid relying on stereotypes is not an effective way of permanently reducing bias.").

283 The concept of mindfulness relies on slowing down to notice one's mental processes, and then using awareness to act thoughtfully rather than "falling back on pre-existing 
incorporating mindfulness into decision-making processes is a laudable goal for any individual, especially for those on dean search committees. In practice, however, during the busy and overwhelming process of a dean search, ${ }^{284}$ committee members are unlikely to appreciate a chair who slowed meetings down in an effort to reinforce reflective thinking.

Taking the IAT: One experienced implicit bias researcher, who has trained numerous law faculties, found that "it is surprising how few faculty members have taken even one IAT," probably because law faculty view themselves as "egalitarian and free from implicit biases." 285 If all faculty and staff members who participated in a dean search committee were encouraged or required to take IATs before the dean search process began, especially on the primary categories affecting the selection of deans (such as race, gender, sexual orientation, etc.), the results could be illuminating. To protect privacy, committee members need not share the results of the IATs with each other, but knowledge of their own biases would be a useful starting point heading into the search.

Mentorship: Individuals could also take action to increase mentorship of diverse candidates for dean positions. Deans and former deans tend to be generous with their experience, and many candidates who are interested in a dean position may find mentors in former or current deans from other schools. ${ }^{286}$ Law schools and the Society of American Law Teachers (SALT) have co-sponsored conferences designed "to encourage and assist members of underrepresented groups to pursue deanships and other university and law school leadership positions." 287

This type of workshop formalizes mentorship opportunities for potential dean candidates. Future workshops across the country could be modeled on similar mentoring programs already in existence for law faculty. ${ }^{288}$ Effective leadership mentoring, especially for diverse candidates

stereotypes." Jeremy D. Fogel, On Being Mindful, in Enhancing Justice: Reducing Bias 353, 354 (Sarah E. Redfield ed., 2017).

284 See Gouvin, Looking for a Leader, supra note 61, at 1 (A dean search is "a huge amount of work").

285 E-mail from Anonymous Implicit Bias Expert to Michele Benedetto Neitz, Professor of Law, Golden Gate Univ. Sch. of Law (July 13, 2018, 5:28 A.M.) (on file with author).

286 Interview with Rachel Van Cleave, Former Dean, Golden Gate Univ. Sch. of Law , in S.F., Cal. (July 23, 2018). The ABA hosts a "New Deans Seminar" each year for newly hired law school deans. See Deans Workshop Committee, AM. BAR Ass'N., https://www.americanbar.org/groups/legal_education/committees/deans_workshop.html (last visited Nov. 28, 2018).

287 SALT Co-Sponsors Diversity in Law Leadership Workshop, Seattle, Sept. 19-20, SOC'Y AM. L. TCHRS. (July 17, 2014), https://www.saltlaw.org/salt-co-sponsors-diversity-inlaw-leadership-workshop-seattle-sept-19-20/.

288 For example, SALT and other organizations regularly host "faculty development workshops" (FDW) for diverse faculty members. See 2018 SALT Teaching Conference \& SALT/LatCrit Junior Faculty Development Workshop, SoC'Y AM. L. TCHRS., 
who are not currently in academia or may not have previously considered becoming deans, could increase and diversify the applicant pool for dean positions.

\section{B. De-biasing Techniques for Institutions}

As research in implicit bias becomes more developed, the attention of many experts has shifted from a focus on the individual to "bias mitigation strategies at the systems, or organizational level." 289 As an institution, a law school could make a stated commitment to reduce implicit bias in hiring for all positions, not just a dean position. ${ }^{290}$ As the leader of the law school, "a dean is in a unique position to make some significant progress towards diversity."291 A dean search provides the opportunity for institutions to implement several de-biasing strategies.

Selection of Chair: Progress could begin with the existing dean or university leadership's selection of the chair of a new dean search committee. In most law schools, chairs are likely to be tenured faculty members who do not themselves have decanal aspirations. Although chairing a dean search is an extraordinary amount of work, ${ }^{292}$ leaders of these committees have the opportunity - and responsibility — to ensure the dean search is conducted without bias.

"Bias Climate" Survey: The chair should first consider the structural biases that may already exist at the law school, including a school's record (or lack thereof) of hiring diverse candidates for leadership positions. The chair should also consider whether diverse leaders choose to stay at the school. A survey would assist the chair in finding hidden biases that may exist in the institution.

Composition of Committee: As discussed, chairs should consider carefully the composition of the dean search committee including diversity

https://www.saltlaw.org/events/2018-salt-teaching-conference-saltlatcrit-facultydevelopment-workshop/ (last visited Feb. 5, 2019) ("The FDW is designed for critical, progressive, and social justice oriented pre-tenure professors, including clinicians and legal writing professors, as well as those who may be contemplating a law teaching career. The FDW familiarizes junior faculty with LatCrit and SALT principles and values and support them in the scholarship, teaching, and service aspects of professional success.").

289 Lieberman et al., supra note 197, at 3.

290 See Levinson \& Young, supra note 236, at 40 (An effective "intervention for reducing implicit biases would be for members of the legal profession to commit to hiring women in counterstereotypical (implicit male prototype) roles. Making such a policy choice for the purpose of implicit gender bias reduction can be supported by social science evidence.") (footnotes omitted).

291 Jennifer L. Rosato, Reflections of a Reluctant Pioneer, 48 CAL. W. L. REV. 445, 449 (2012).

292 See Gouvin, Looking for a Leader, supra note 61, at 1. 
along racial, gender, sexual orientation, and other lines. ${ }^{293}$ Additionally, chairs should consider the role that non-tenured faculty, including legal writing faculty and clinicians, will play in the process. Chairs should ensure that their privileged status as tenured faculty members does not inadvertently lead them to exclude staff opinions during the process.

Culture and Reputation Considerations: It is also critical that a dean search committee conduct an assessment of the law school's culture at the beginning of the search. This could include consideration of the law school's reputation in the larger legal community. ${ }^{294}$ For example, whether there is a specific type of candidate who might feel uncomfortable on campus. If so, how to address this concern head-on as a committee or in a larger faculty meeting. A frank discussion with colleagues may benefit the law school in the long run, since "[r]esearchers have ... found that carefully confronting people with their biases can reduce implicit bias." 295 While care should be taken to avoid creating defensiveness among faculty members, a dean search chair should be ready to "move beyond collegiality" if necessary to ensure the process is not biased. ${ }^{296}$

Objective Factors and Scoring Interviews: A list of objective factors the committee is seeking in a dean should be based on the committee's findings during the listening tour of the larger school community. With these factors in hand, questions should be prepared before the first interview and evaluated by all committee members for potential bias. Sample questions are readily available; as discussed above, ${ }^{297}$ participants in a recent conference to promote diversity in law school leadership proposed sample interview questions for dean search committees. Moreover, while every interview is different, using the same interview questions for each candidate and evaluating the interview on the same factors will move the process in a more objective direction.

Implicit Bias Training: An increasing number of law schools and universities are offering formal implicit bias trainings for their employees. For example, Northwestern University's website presents "a list of specific

293 See George C. Chen, Beneath the Surface: Why Diversity and Inclusion Matter for Lawyers of Color, and What Lawyers Can Do to Address Implicit Bias in the Legal Profession, FED. LAw., June 2015, at 28, 30 (recommending the inclusion of people of color in leadership roles); see also supra Part III.B.1.

294 See Gouvin, Looking for a Leader, supra note 61, at 10 ("Doing this homework ahead of time will inform you of the existing preconceptions and misconceptions about your institution in the legal community.").

295 Levinson \& Young, supra note 236, at 39. Leading this type of uncomfortable discussion may make a dean search chair unpopular, but frankly the chair was destined to be unpopular the moment he or she was assigned to lead the dean search.

296 Deo, supra note 158 , at 481.

297 See supra Part III.B.2.v. 
interventions for addressing unconscious bias in the context of faculty recruitment." ${ }^{298}$ Carnegie Mellon University and Dartmouth University both recommend that search committees across the universities attend some form of implicit bias training. ${ }^{299}$ The Executive Associate Dean of Faculties at Texas A\&M University prepared an extensive slide deck entitled "Search Committee Training," with special focus on overcoming implicit biases in a search process. ${ }^{300}$

The effectiveness of formal implicit bias training is controversial. ${ }^{301}$ At a minimum, however, the increasing number of implicit bias trainings for search committees in universities signals a shifting culture in higher education. University leaders, including law school leadership, are more mindful of the ways that bias can affect search committees. Even so, the statistics show that trainings do not necessarily translate to diversity in deans chosen for the job. ${ }^{302}$

298 Office of the Provost, Resources on Unconscious Bias: Strategies for Minimizing the Impact of Bias in Recruitment, Nw. U., http://www.northwestern.edu/provost/facultyresources/faculty-search-committees/unconscious-bias.html (last visited Nov. 28, 2018).

299 Provost, Increase Faculty Diversity: Provide Implicit Bias Training for Faculty Search Committees, DARTMOUTH U., http://inclusive.dartmouth.edu/provide-implicit-biastraining-faculty-search-committees (last visited Oct. 27, 2018); Vice Provost for Faculty, Understanding Implicit Bias Research and Its Implications, CARNEGIE MELLON U., http://www.cmu.edu/faculty-office/faculty-recruitment/understanding-implicit-bias.html (last visited Oct. 27, 2018).

300 Blanca Lupiani, Tex. A\&M U., Search Committee Training (2017), https://dof.tamu.edu/dof/media/PITO-DOF/Documents/Guidelines/presentations/Dr-

Lupiani-s-Search-Committee-Training-Spring-2017_1.pdf. These trainings should also include issues of cultural proficiency, since "[t]raining law professors in culturally proficient instruction is the threshold step in building a culturally proficient legal profession." Anastasia M. Boles, Seeking Inclusion from the Inside Out: Towards A Paradigm of Culturally Proficient Legal Education, 11 CHARLESTON L. REV. 209, 268 (2017).

301 Social psychologists have found that "interventions that directly target implicit bias appear to be ineffective." Patrick S. Forscher \& Patricia G. Devine, Knowledge-Based Intervention Are More Likely to Reduce Legal Disparities than Are Implicit Bias Interventions, in ENHANCING JUSTICE: REDUCING BIAS 289, 291 (Sarah E. Redfield ed., 2017). One professor at a law school implementing diversity measures explained: "I am not a huge fan of implicit bias training. I am certainly a fan of anti-discrimination training and efforts to be more inclusive especially in respect to LGBT individuals, but the implicit bias training I think has come off the rails a little bit." Crystal Nieves Murphy \& Lauren Peller, Faculty Left in the Dark as Law School Implements Diversity Measures, GW HATCHET (Oct. 19, 2017), https://www.gwhatchet.com/2017/10/19/faculty-left-in-the-dark-as-law-school-implementsdiversity-measures/. But see Negowetti, supra note 144, at 956 ("[A]11 attorneys involved in hiring decisions should receive comprehensive training on implicit bias that will keep them attuned to the subtle and unconscious ways that ... bias can negatively affect all aspects of employment.").

302 For a discussion of diversity statistics, see supra Part III.C. 
Additional Suggestions for the Committee Chair: To minimize bias, dean search committee chairs should:

- Provide copies of the law school's non-discrimination policy to every member of the committee, and discuss any questions or concerns.

- Ask faculty and staff members to identify resources to reach communities of color, LGBTQ communities, and non-traditional candidates.

- Work with university leadership to craft a job posting that would attract diverse applicants. The use of language is important. For example, masculine words in a job posting, such as "dominant" or "strong," instead of more neutral words such as "excellent," may create a negative reaction among readers. ${ }^{303}$

- Ensure the dean job posting is advertised broadly to various communities, both inside and outside of the legal profession.

- Create an environment of candor and honest communication in committee meetings.

- Take time to speak on the telephone or in person with potential candidates. These conversations can identify any perceived reputational flaws with the position or the school, gauge candidate interest, and encourage nontraditional candidates to apply.

- Meet with each dean search committee member individually throughout the process to check in about issues of bias. Discern whether there is any bias on the part of any committee member that must be addressed, and how committee members feel about the pool of candidates before interviews begin.

- Discuss any potential implicit bias with the president and/or provost before the final candidate is selected.

\section{Change the Dean Search Process}

Although law schools are notoriously slow to change, the Great Recession created a more lively spirit of entrepreneurship among law schools. Dean search committees should "utilize novel and creative recruiting tools to get diverse candidates in the door." 304 These creative methods might require dean search chairs to radically re-imagine the traditional dean search process. ${ }^{305}$

303 Abigail J. Stewart \& Virginia Valian, Recruiting Diverse and Excellent New Faculty, INSIDE HIGHER ED (July 19, 2018), https://www.insidehighered.com/advice/2018/07/19/advi ce-deans-department-heads-and-search-committees-recruiting-diverse-faculty? width $=775 \&$ height $=500 \&$ iframe $=$ true

304 Deo, supra note 158, at 475.

305 Some may question whether the role of a dean is even necessary. See, e.g., Bill L. Williamson, The "Art" of Deaning, 36 J. LEGAL EDUC. 227, 227 (1986) (arguing against 
Diverse Leadership Conferences: One way for a law school to attract nontraditional candidates would be to host a conference about administrative leadership generally, or diversity in leadership, in an effort to attract leaders from law practice or other industries who may ultimately prove to be good dean candidates. Search committees could begin interviewing candidates at the conference, or (at a minimum) encourage conference participants to apply for an upcoming dean opening.

Dean Search Registry: Another reform idea would involve collaboration among law schools across the county. Professor Gouvin, a former dean search committee chair, was disappointed with the lack of diversity in his search committee's pool. Professor Gouvin believes that " $[t]$ he current system creates a bias in favor of dean candidates that have contacts in the academy, and that may be an important selection criterion for a dean." 306 Essentially, Professor Gouvin argues that in-group favoritism irreversibly biases the dean pool.

To combat this bias, Professor Gouvin proposed the creation of a "dean candidate registry" similar to the AALS Faculty Appointments Register. ${ }^{307}$ This registry would be available for "all [interested] applicants and would get the names of potential candidates before search committees even when the candidates are not connected to the school's existing 'old boy' referral network." ${ }^{308}$ In addition to lowering the costs for applicants, who would not need to spend extensive time researching and applying to individual dean postings, this could serve as a tool to "identify minority and women candidates." ${ }^{09}$ A central registry would also enable search committee chairs to easily survey the pool of candidates and broaden the resume review process.

It is possible, however, that nontraditional candidates would not participate in this type of registry, either because they do not know about it, they are concerned about the impression it would give to their current employers, or because they have not considered a deanship as a career option. One former dean, who served as an executive director of a nonprofit before becoming a dean, believes that a registry might exclude candidates who would be good deans but do not think of academia as a viable option. ${ }^{310}$ Moreover, "[m]any faculty, especially at elite institutions, would find it humiliating to put themselves forward that way given [the] possibility of

\footnotetext{
having a dean at all and proposing instead a revolving chairpersonship, such as the type used for faculty committees).

306 Gouvin, Register This!, supra note 125.

307 Id.

308 Id.

309 Id.

310 Interview with Dru Ramey, Former Dean, Golden Gate Univ. Sch. of Law, in S.F., Cal. (July 10, 2018).
} 
rejection." 311 Also, the registry would only be effective if multiple schools chose to employ it during dean searches. These issues would need to be addressed if such a registry were created.

Data Collection: Even without a registry, there should be more data collection related to dean searches. For example, the AALS could collect demographic data about applicants, screening interviews, and finalists. This would help to determine more clearly at what point in the process diverse candidates might be screened out. For example, if that stage turned out to be the selection by a president or provost, it would clarify where implicit bias training and assessment may be helpful. On the other hand, "if [it is] at the point of screening interviews, that would call for different solutions." 312 This data could also serve to "uncover any differences (or not) between search firm searches versus university/law school-run searches." 313 At a minimum, additional data would provide needed transparency about dean search processes across the country.

\section{CONCLUSION}

The role of the law school dean requires greater flexibility and entrepreneurial thinking as the legal profession moves forward from the Great Recession. Moreover, the best fit for a deanship can only be found when all potential candidates are considered. Recognizing these challenges, dean search committees should seek to diversify the pool of dean candidates. As one recently hired dean explained, however, this will not happen without commitment on the part of search committee members and the larger school community. Indeed:

[A]t the end of the day, [what] will make for a more diverse dean pool is both an institutional and a personal commitment on the part of selection committee members to seek greater diversity. This must stem from a conviction that there is a value to legal education and the profession to have LGBTQ people as deans, or African-Americans as deans, or Latinos as deans - and so on. ${ }^{314}$

One roadblock to a more diverse pool is the prevalence of implicit bias in the dean search process, especially based on race, gender, sexual orientation, and socioeconomic status. As committees become more cognizant of the ways bias and in-group favoritism can influence a selection

\footnotetext{
311 E-mail from Deborah Rhode, supra note 113.

312 E-mail from Rachel Van Cleave, Former Dean, Golden Gate Univ. Sch. of Law, to Michele Benedetto Neitz, Professor of Law, Golden Gate Univ. Sch. of Law (July 27, 2017, 6:24 PM) (on file with author).

313 Id

314 Telephone Interview with Colin Crawford, Dean, Louis D. Brandeis Sch. of Law, Univ. of Louisville, Louisville, Ky. (June 28, 2018).
} 
process, law schools should take more creative steps to achieve diversity in leadership. The implementation of bias training for individuals and institutions would be an excellent start, but this could also include more radical changes to the search process, such as a dean search registry. Diversifying the dean candidate pool will ultimately create a more balanced and representative law school community, benefiting the legal profession as a whole. 